\title{
High-pressure/ultrahigh-pressure eclogites from the Hong'an Block, East-Central China: geochemical characterization, isotope disequilibrium and geochronological controversy
}

Received: 2 September 2004 / Accepted: 7 March 2005/Published online: 16 April 2005

(C) Springer-Verlag 2005

\begin{abstract}
The Hong'an Block (western Dabieshan) exposes a series of HP/UHP metamorphic rocks, with a Sto-N distribution from blueschist-greenschist, kyanitefree, to kyanite- and coesite-bearing eclogites. The available age data are inconclusive that hinder our understanding of the tectonic evolution of the Block. The metamorphic temperatures in the Hong'an Block ( $T_{\text {meta }} \approx 700$ to $500^{\circ} \mathrm{C}$ ) are lower by $50-150^{\circ} \mathrm{C}$ than that of the Dabie and Sulu terranes. In this work, we undertook new trace element and $\mathrm{Sr}-\mathrm{Nd}-\mathrm{O}$ isotopic analyses on minerals in order to gain more insight into the geochronological problems. The results are as follows: (1) Trace element distribution patterns suggest that garnet and omphacite in many cases are out of chemical equilibrium; and the presence of high-temperature LREE-rich mineral inclusions (e.g., epidote) in garnet and omphacite has contributed to isotope disequilibrium. (2) $\mathrm{Sm}-\mathrm{Nd}$ isotope analyses yielded no isochron ages for the Hong'an eclogites. (3) $\mathrm{Rb}-\mathrm{Sr}$ isotope analyses gave mixed results; in some cases, coexisting minerals are completely out of isotope equilibrium, and in others, isochron relationship is established, yielding ages
\end{abstract}

Electronic Supplementary Material Supplementary material is available for this article at http://dx.doi.org/10.1007/s00410-0050668-5

Editorial Responsibility: J. Hoefs

B. Jahn $(\square) \cdot$ T.-F. Yui

Institute of Earth Sciences, Academia Sinica,

Taipei, 115, Taiwan

E-mail: jahn@earth.sinica.edu.tw

B. Jahn $\cdot$ X. Liu

Department of Geosciences, National Taiwan University,

P. O. Box 13-318, Taipei, 10699, Taiwan

X. Liu

Institute of Geomechanics, CAGS,

Beijing, 100081, China

N. Morin · M. B.-L. Coz

Géosciences Rennes, Université de Rennes 1,

35042 Rennes Cedex, France from $210 \mathrm{Ma}$ to $225 \mathrm{Ma}$. The pattern of $\mathrm{Rb}-\mathrm{Sr}$ isotope disequilibrium appears to be independent of the petrological and O-isotope temperatures. (4) In contrast to the unequilibrated $\mathrm{Sm}-\mathrm{Nd}$ isotopic systems, oxygen isotopes of the eclogite minerals seem to have attained isotope equilibrium or near-equilibrium. Oxygen isotope temperatures are comparable with petrological temperatures. However, this is an apparent feature due to mass balance constraints. (5) Whole-rock $\delta^{18} \mathrm{O}$ values show a large variation from $+10 \%$ to $-8 \%$, suggesting that their protoliths have undergone very different processes of water-rock interaction. In view of the overall geochronological information, we conclude that the HP/ UHP metamorphism in the Hong'an Block took place in the Triassic at about $220-230 \mathrm{Ma}$, as observed in the Dabie and Sulu terranes. The significance of published Paleozoic dates (450-300 Ma) for the Xiongdian eclogite is not clear. However, any hypotheses advocating two periods of UHP metamorphic events for the same tectonic unit or in the same locality are not constrained by the geochronological data.

\section{Introduction}

The Qinling-Dabie orogen marks the suture zone between the Sino-Korean and Yangtze cratons. Highpressure (HP) and ultrahigh-pressure (UHP) metamorphic rocks in this orogen extend from eastern Qinling, through Tongbaishan and Dabieshan, across the Tanlu fault, and then northeastwards to the Sulu region (Fig. 1). The Hong'an Block, also known as western Dabieshan, exposes a series of high $P / T$ metamorphic rocks, with a S-to-N distribution from blueschist/ blueschist-greenschist, kyanite-free and kyanite- and coesite-bearing eclogite facies rocks. The Block, as compared with other parts of the Qinling-Dabie orogen, has been considered to conserve better archives for the understanding of the tectonic evolution of this orogen 
Fig. 1 Simplified geological map of the Hong'an Block (also known as western Dabieshan) showing different tectonic units and five eclogite zones. The inset shows the location of the Hong'an Block with respect to the Qinling-Dabie-Sulu orogen of China. The metamorphic grades generally increase from SW to NE. Eight sampling localities are shown

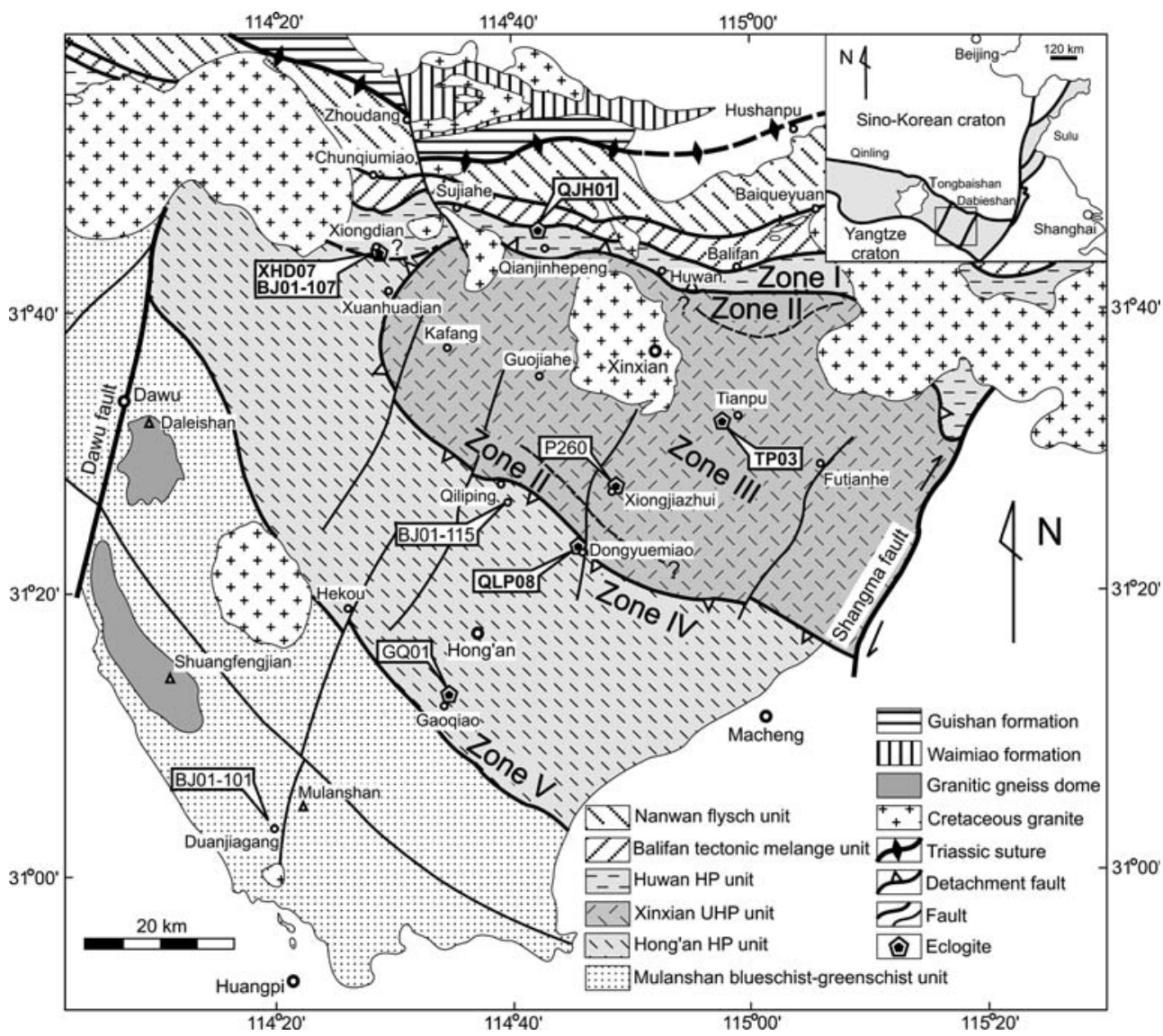

for three main reasons (e.g., Eide and Liou 2000): (1) it is least affected by the thermal and structural overprint imposed on much of the Dabie terrane during the intrusion of voluminous Cretaceous granitoids; (2) HP eclogites are widespread in the Hong'an Block and they often preserve prograde metamorphism, and can be directly linked to the blueschist/blueschist-greenschist rocks; (3) in comparison with the Dabie terrane, the better exposure of blueschist/blueschist-greenschist facies rocks offers opportunities for simultaneous structural and metamorphic analyses.

The collision between the two Precambrian cratons, Yangtze and Sino-Korean, leading to the formation of UHP metamorphic terranes is generally accepted to have taken place in the Triassic (Ames et al. 1993, 1996; Li et al. 1993, 1994, 2000; Eide et al. 1994; Chavagnac and Jahn 1996; Rowley et al. 1997; Maruyama et al. 1998; Hacker et al. 1998, 2000; Chavagnac et al. 2001; Ayers et al. 2002; Jahn et al. 2003a; Yang et al. 2003). However, the published age data of eclogites from the Hong'an Block have caused much controversy. Some investigators argued that the HP eclogites in the northern eclogite zone (so-called Huwan shear zone) of the Block could have formed in a Paleozoic subduction zone of an oceanic plate beneath the Sino-Korean craton (Jian et al. 1997, 2000; Xu et al. 2000; Li et al. 2001; Sun et al. 2002). Such an interpretation appears to be in conflict with the scenario that the orogen-scale structure of Dabieshan is a huge antiform with UHP eclogites at the core and HP eclogites on the two limbs (Hacker et al. 1998, 2000; Eide and Liou 2000). Indeed, the nature and age of the northern HP eclogite zone and its relation to other HP/UHP eclogites have become a highly controversial issue in the last few years (Fu et al. 2002; Gao et al. 2002; Jahn and Liu 2002; Jahn et al. 2003b; Ratschbacher et al. 2003).

The motivation of the present work is to resolve the apparent conflict and to find a satisfactory explanation for the complex age patterns. During our isotope analyses, we have found that isotopic disequilibrium is the major cause of the age problem. In order to better evaluate the isotope behavior, we have also made comprehensive geochemical and oxygen isotope analyses on whole-rock and constituent minerals. In the end, we will summarize the available meaningful age data and conclude that the Hong'an Block shared the same metamorphic evolution as the Dabie and Sulu terranes. The controversial Paleozoic ages reported in the literature for the eclogites from the Xiongdian locality will be discussed.

\section{Geological setting and age controversy}

The Hong'an Block is separated from Tongbaishan in the west by the Dawu Fault, and from the Dabie 
terrane by the Shangma Fault (Fig. 1). A variety of HP and UHP metamorphic rocks and structures are well preserved and the Cretaceous tectonic and thermal overprint is generally weak or absent. Based on the petrological characteristics, six major lithotectonic units, comprising five eclogite zones, can be distinguished (Hacker et al. 1996; Liou et al. 1996; Zhong et al. 1999, 2001; Liu et al. 2004a). They are, from north to south, the Nanwan flysch unit, the Balifan tectonic mélange unit, the Huwan HP unit, the Xinxian UHP unit, the Hong'an HP unit, and the Mulanshan blueschist-greenschist unit (Fig. 1). The details about the lithological characteristics of all individual units can be found in Liu et al. (2004a).

In contrast to the well-dated Dabie and Sulu terranes, geochronological studies in the Hong'an Block are scarce. The earlier Ar-Ar dating work of Eide et al. (1994) suggests that the Hong'an Block is a part of the Dabieshan Triassic HP/UHP metamorphic belt. Since then, several attempts of U-Pb zircon dating on eclogites from the northwestern corner of the Huwan unit have produced a wide range of metamorphic ages from Silurian to Triassic (Jian et al. 1997, 2000; Xu et al. 2000; Li et al. 2001; Sun et al. 2002; Gao et al. 2002). Presence of two distinct Paleozoic U-Pb zircon ages of about 400 and $300 \mathrm{Ma}$ for the Xiongdian eclogite was first reported (TIMS method) and then reconfirmed (SHRIMP method) by Jian and his collaborators (Jian et al. 1997, 2000). The date of ca. $400 \mathrm{Ma}$ was interpreted as the minimum age for the eclogite facies metamorphism and the $300 \mathrm{Ma}$ as the time of retrograde metamorphism. Meanwhile, $\mathrm{Xu}$ et al. (2000) obtained phengite ${ }^{40} \mathrm{Ar} /{ }^{39} \mathrm{Ar}$ dates of $350-$ $430 \mathrm{Ma}$ for the same eclogite, and interpreted the dates as a retrograde metamorphic age. More recently, using SHRIMP U-Pb dating, Sun et al. (2002) obtained a Carboniferous metamorphic age of $309 \pm 3 \mathrm{Ma}$ for the zircon rims of three eclogite samples from the Xiongdian and adjacent Hujiawan localities. The age was interpreted as the time of a HP metamorphic event. In addition, ages ranging from $350 \mathrm{Ma}$ to $440 \mathrm{Ma}$ were also obtained for zircon cores from the same samples. Sun et al. (2002) interpreted these ages as the time of igneous intrusion or lowpressure metamorphism in the southern margin of the Sino-Korean craton. These authors also reported a protolith age of $752 \pm 17 \mathrm{Ma}$ and a Triassic metamorphic age of $232 \pm 10 \mathrm{Ma}$ for an eclogite from Xuanhuadian, about 5-km south of Xiongdian. They concluded that two sutures, a Carboniferous and a Triassic, existed on the two sides of the Huwan unit, and insisted that the Carboniferous eclogites were not affected by the Triassic eclogite facies event. However, Gao et al. (2002) simultaneously reported a Triassic SHRIMP zircon age of $216 \pm 4 \mathrm{Ma}$ for precisely the same Xiongdian eclogite. It is clear that inspite of using the same SHRIMP U-Pb dating technique on the same eclogite, the results have not always been consistent.

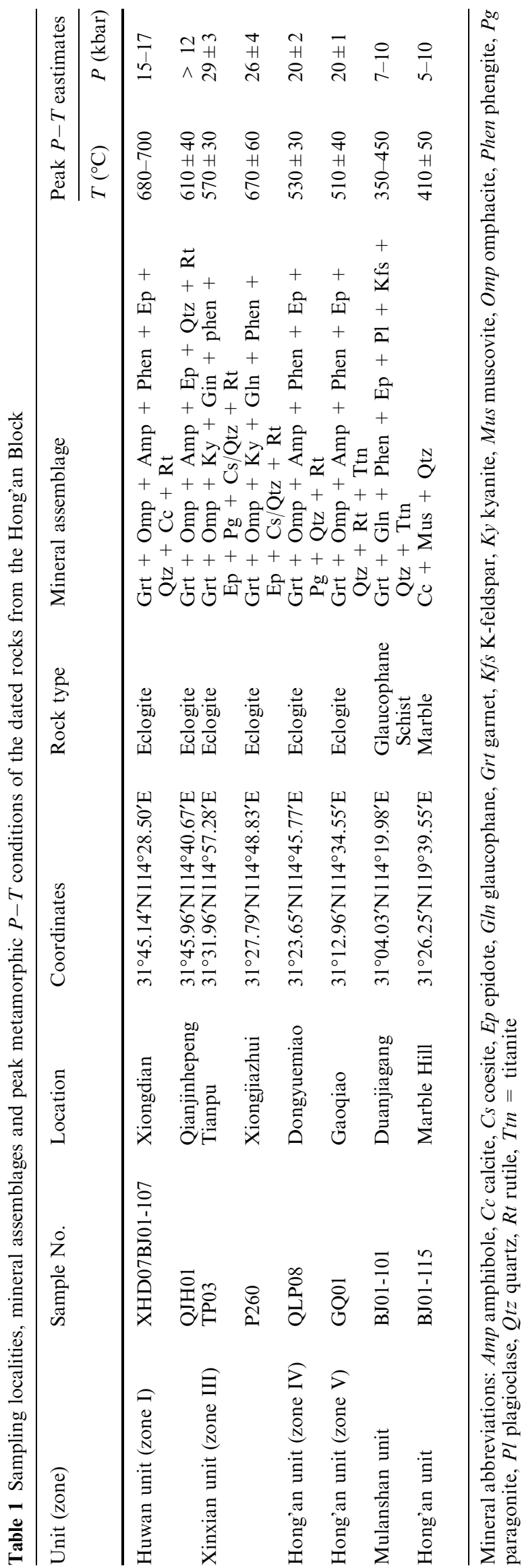




\section{Petrology and $\boldsymbol{P}-\boldsymbol{T}$ conditions of analyzed samples}

The sampling localities are shown in Fig. 1, and the mineral assemblages and peak metamorphic conditions are summarized in Table 1 . The $P-T$ calculations were performed using the garnet-clinopyroxene thermometry (Powell 1985), jadeite-albite-quartz and garnet-clinopyroxene-phengite barometry (Carswell and Harley 1990; Carswell et al. 1997) and THERMOCALC program (Powell et al. 1998). For details, see Liu et al. (2004a). Six basaltic eclogites were analyzed in this work. In addition, a glaucophane schist (sample BJ01101) from Duanjiagang locality (near Mulanshan) in the Mulanshan blueschist-greenschist unit and a marble (sample BJ01-115) from Shihuishan (Marble Hill) in the Hong'an unit were also analyzed. Their petrographic characteristics are given in Appendix 1.

Briefly, the peak metamorphic temperatures of eclogites from the Hong'an Block range from ca. $500^{\circ}$ to $700^{\circ} \mathrm{C}$, which are lower than those recorded in the Dabie and Sulu terranes at corresponding pressures (Fig. 2; Zhang and Liou 1994; Liou et al. 1996, 2004a; Eide and

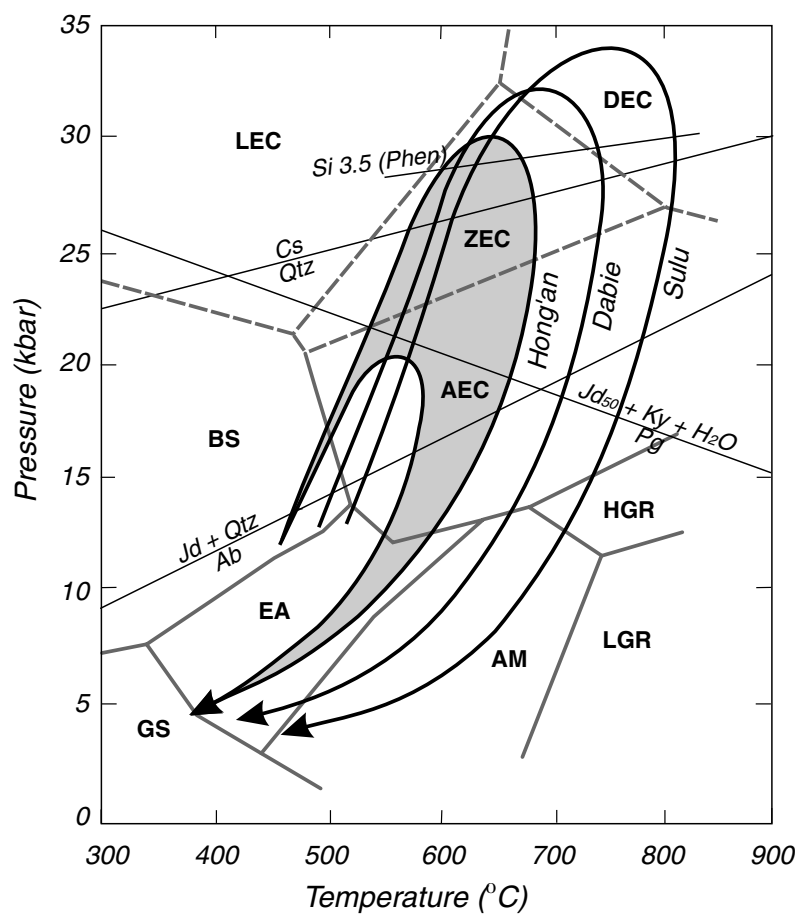

Fig. 2 Metamorphic $P-T$ paths of three UHP terranes in the Dabie-Sulu orogen (modified after Zhang and Liou 1994; Eide and Liou 2000; Liu et al. 2004a). Note that the $P-T$ conditions generally decrease from the Sulu through Dabie to Hong'an. The petrogenetic grid is from Liou et al. (1998). The reaction curves for Qtz $=\mathrm{Cs}, \mathrm{Pg}=\mathrm{Jd}_{50}+\mathrm{Ky}+\mathrm{H}_{2} \mathrm{O}, \mathrm{Ab}=\mathrm{Jd}+$ Qtz and phengite $\mathrm{Si}=3.5$ are from Bohlen and Boettcher (1982), Newton (1986), Holland (1980) and Zhang and Liou (1994), respectively. Abbreviations for facies names: $A M$ amphibolite; $B S$ blueschist; $E A$ epidote amphibolite; $G S$ greenschist; $H G R$ high-pressure granulite; $L G R$ low-pressure granulite; $A E C$ amphibole eclogite; $D E C$ dry eclogite; $L E C$ lawsonite eclogite; $Z E C$ zoisite eclogite
Liou 2000). The eclogites from the Hong'an and Huwan units have often been referred to as "cold eclogites" and no coesite has been identified. Note that the temperature range $\left(500-700^{\circ} \mathrm{C}\right)$ is roughly at the threshold of the blocking temperatures for two important chronometers involved in study of UHP metamorphic rocks: garnet $\mathrm{Sm}-\mathrm{Nd}$ and white-mica $\mathrm{Rb}-\mathrm{Sr}$ systems (see later for discussion).

\section{Analytical procedures}

\section{Elemental abundances}

Major and trace element abundances were measured using XRF (3080E) at the National Research Center for Geoanalysis, Chinese Academy of Geological Sciences, and ICP-MS (Elan 6100DRC) at the Key Laboratory of Continental Dynamics, Northeast University (Xi'an), respectively. The uncertainties for trace elements vary from $<5 \%$ to $<20 \%$ depending on the concentration levels.

Chemical analyses of mineral grains were performed using an ICP-MS (HP-4500) laser ablation technique in Rennes. Mineral grains were analyzed by the line-scan mode with a continuous laser shot (energy 15-10 Hz) for $90 \mathrm{~s}$, with a beam size of $25 \mu \mathrm{m}$, moving at a speed of $1 \mu \mathrm{m} / \mathrm{s}$. A total of five to ten tracks were measured for each individual mineral. Elemental concentrations were obtained by calibration with respect to standards NIST 610-612-614-616. The calibration range followed the concentration levels of individual minerals. An internal standardization was adopted using ${ }^{29} \mathrm{Si}$, assuming $\mathrm{SiO}_{2}$ content equal to $72 \%$, and all elemental concentrations were calculated and normalized using the ratio of sample $\mathrm{SiO}_{2}$ to NIST $\mathrm{SiO}_{2}$. In the course of the analyses, we assumed the $\mathrm{SiO}_{2}$ content to be $39 \%$ for garnet, $56 \%$ for clinopyroxene and $45 \%$ for amphibole.

\section{$\mathrm{Sr}-\mathrm{Nd}$ isotopic analyses}

The analytical procedures for $\mathrm{Sr}-\mathrm{Nd}$ isotopic analyses are similar to those reported earlier (e.g., Jahn et al. 1996; Chavagnac and Jahn 1996). Analytical precision, $\mathrm{Sr}-\mathrm{Nd}$ isotope standard and normalization values, and blank levels can be found in the footnotes of data tables. The decay constants $(\lambda)$ used are $0.0142 \mathrm{Ga}^{-1}$ for ${ }^{87} \mathrm{Rb}$ and $0.00654 \mathrm{Ga}^{-1}$ for ${ }^{147} \mathrm{Sm}$. The depleted mantle based model ages $\left(T_{\mathrm{DM}}\right)$ were calculated assuming a linear isotopic evolution of the mantle from $\epsilon_{\mathrm{Nd}}(\mathrm{T})=0$ at $4.56 \mathrm{Ga}$ to +10 at the present time.

$$
\begin{aligned}
T_{\mathrm{DM}} & =1 / \lambda * \ln \left\{\left[\left({ }^{143} \mathrm{Nd} /{ }^{144} \mathrm{Nd}\right)_{\mathrm{s}}\right.\right. \\
& \left.-0.51315] /\left[\left({ }^{147} \mathrm{Sm} /{ }^{144} \mathrm{Nd}\right)_{\mathrm{s}}-0.2137\right]\right\}
\end{aligned}
$$


$\mathrm{Sm}-\mathrm{Nd}$ isochron ages were computed using the ISOPLOT software of Ludwig (1999). Input errors $(2 \sigma)$ for age computations are ${ }^{87} \mathrm{Rb} /{ }^{86} \mathrm{Sr}=2 \%,{ }^{87} \mathrm{Sr} /{ }^{86} \mathrm{Sr}=$ $0.005 \%,{ }^{147} \mathrm{Sm} /{ }^{144} \mathrm{Nd}=0.2 \%,{ }^{143} \mathrm{Nd} /{ }^{144} \mathrm{Nd}=0.005 \%$. These input errors of $0.005 \%$ for ${ }^{87} \mathrm{Sr} /{ }^{86} \mathrm{Sr}$ and ${ }^{143} \mathrm{Nd} /{ }^{144} \mathrm{Nd}$ were estimated from the reproducibility of long-term measurements on standards and they represent about five times the in-run precision $\left(2 \sigma_{\mathrm{m}}\right)$ reported in Table 4. The quoted error in calculated ages throughout this paper represents two standard deviations $(2 \sigma)$.

\section{O isotopic analyses}

O-isotope analyses were performed with a MAT 252 mass spectrometer at the Institute of Earth Sciences, Academia Sinica, Taipei. Garnet, omphacite, epidote (zoisite) and amphibole were analyzed by the $\mathrm{CO}_{2}$ laser-fluorination method (Sharp 1990). The analytical precision is slightly better than $\pm 0.1 \%$. UWG-2 garnet standard, with a recommended $\delta^{18} \mathrm{O}$ value of $+5.8 \%$ relative to SMOW (Valley et al. 1995), was employed to normalize the daily data. Quartz and phengite, by contrast, were analyzed by the conventional $\mathrm{BrF}_{5}$ method (Clayton and Mayeda, 1963). The precision is better than $\pm 0.2 \%$. The mean $\delta^{18} \mathrm{O}$-value for NBS-28 standard obtained during the present study was $+9.6 \%$.

\section{Geochemical characterization}

Bulk chemical compositions of eclogites

Eclogites from the Dabie terrane can be generally separated into three types based on their field occurrence-Type I are gneiss-hosted enclaves or layers; Type II are interlayers with or enclaves within marble or calcsilicate rocks, and Type III represent members of layered mafic-ultramafic intrusions, such as the Bixiling and Maowu complexes, or simply in association with ultramafic rocks with no clear genetic relationship (Wang et al. 1990; Liou et al. 1996; Jahn 1998). The studied samples from the Hong'an Block are of Type I, and their chemical compositions are quite comparable to the same type of eclogites from the Dabie terrane - all of them show characteristic REE patterns with light-REE enrichment; and depletion in $\mathrm{Nb}$ (and $\mathrm{Ta}$ ) with respect to La in spidergrams. These are also typical features observed in the mafic components of Precambrian gneiss terranes, such as amphibolites or basic granulites (Jahn 1990, 1998).

The eclogites are mainly of basaltic composition, but they show a wide range of major and trace element abundances (e.g., Jahn 1998; Jahn et al. 2003b). This suggests their multiple origins and derivation from heterogeneous mantle sources. However, unusual compositions could be an artifact caused by biased analyses conducted on banded rocks. Eclogites and ultramafic rocks that have recrystallized in UHP metamorphic conditions often show coarse-grained texture with distinct mineral banding of variable scale. It is very difficult to obtain a truly representative bulk composition for the protolith of a banded eclogite. Fine-grained or homogeneous textured eclogites also occur, but they seem to be minor in comparison with heterogeneous textured facies. Eclogites from the Dabie and Sulu terranes have a wide range of $\mathrm{SiO}_{2}$ contents from $36 \%$ to $60 \%$, although the majority ( $>70 \%$ of all types) still have basaltic or gabbroic compositions $\left(\mathrm{SiO}_{2}=45-52 \%\right.$; Jahn 1998). Higher silica eclogites $\left(\mathrm{SiO}_{2} \geq 53 \%\right)$ suggest that their protoliths are more differentiated, and lower silica ones $(\leq 45 \%)$ implies a "cumulate" nature of their protoliths
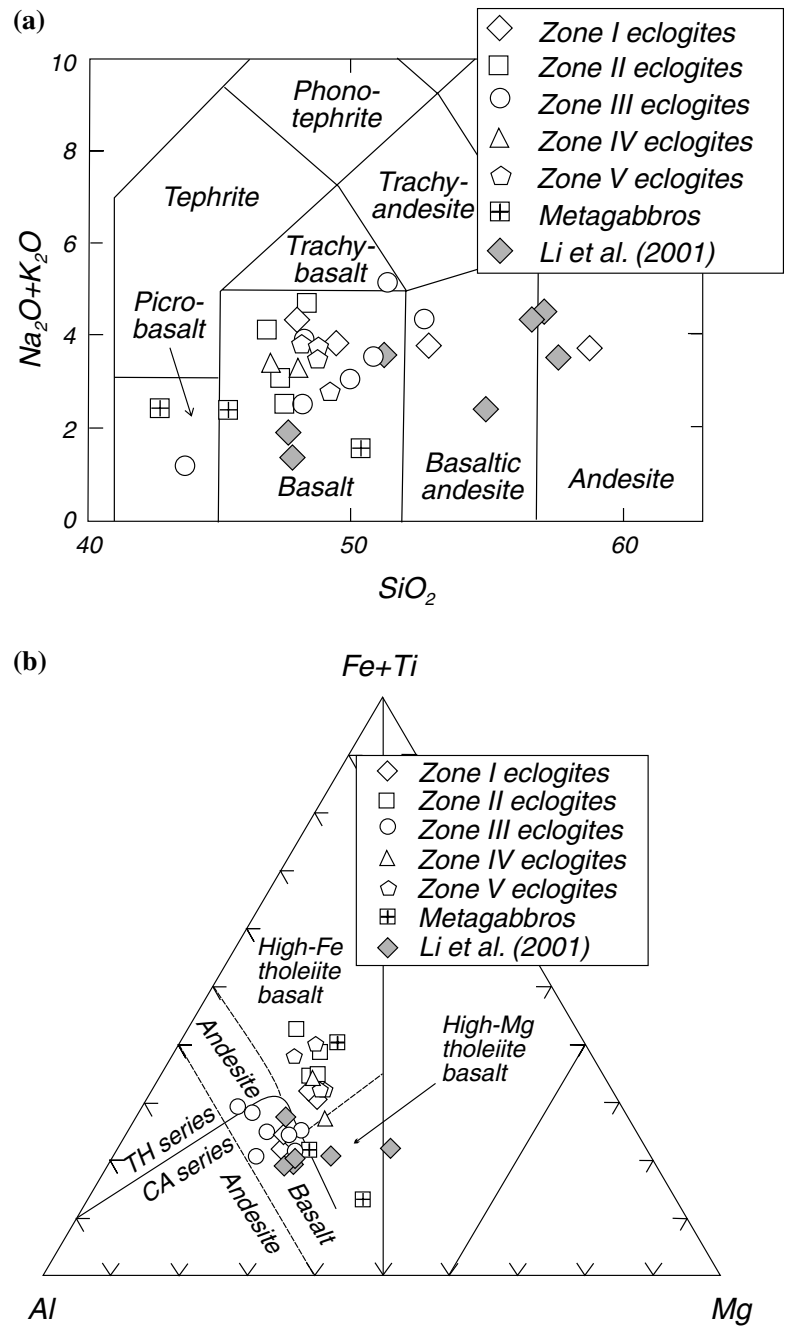

Fig. 3 a Total alkalis versus $\mathrm{SiO} 2$ (TAS) classification (Middlemost 1994) diagram for magmatic rocks. Most eclogites fall in the field of basalt; whereas eclogites from Xiongdian of Eclogite Zone I (Huwan unit), including those reported by Li et al. (2001), show higher silica contents, and fall in andesite and basaltic andesite fields. b Cation plot of Jensen (1976) for metaigneous rocks. All eclogites fall in high-Fe basalt of the tholeiitic series, or in basalt of the calc-alkaline series. The "andesites" in TAS diagram also plot in the basalt fields 
Table 2 Chemical compositions of eclogites from the Hong'an Block

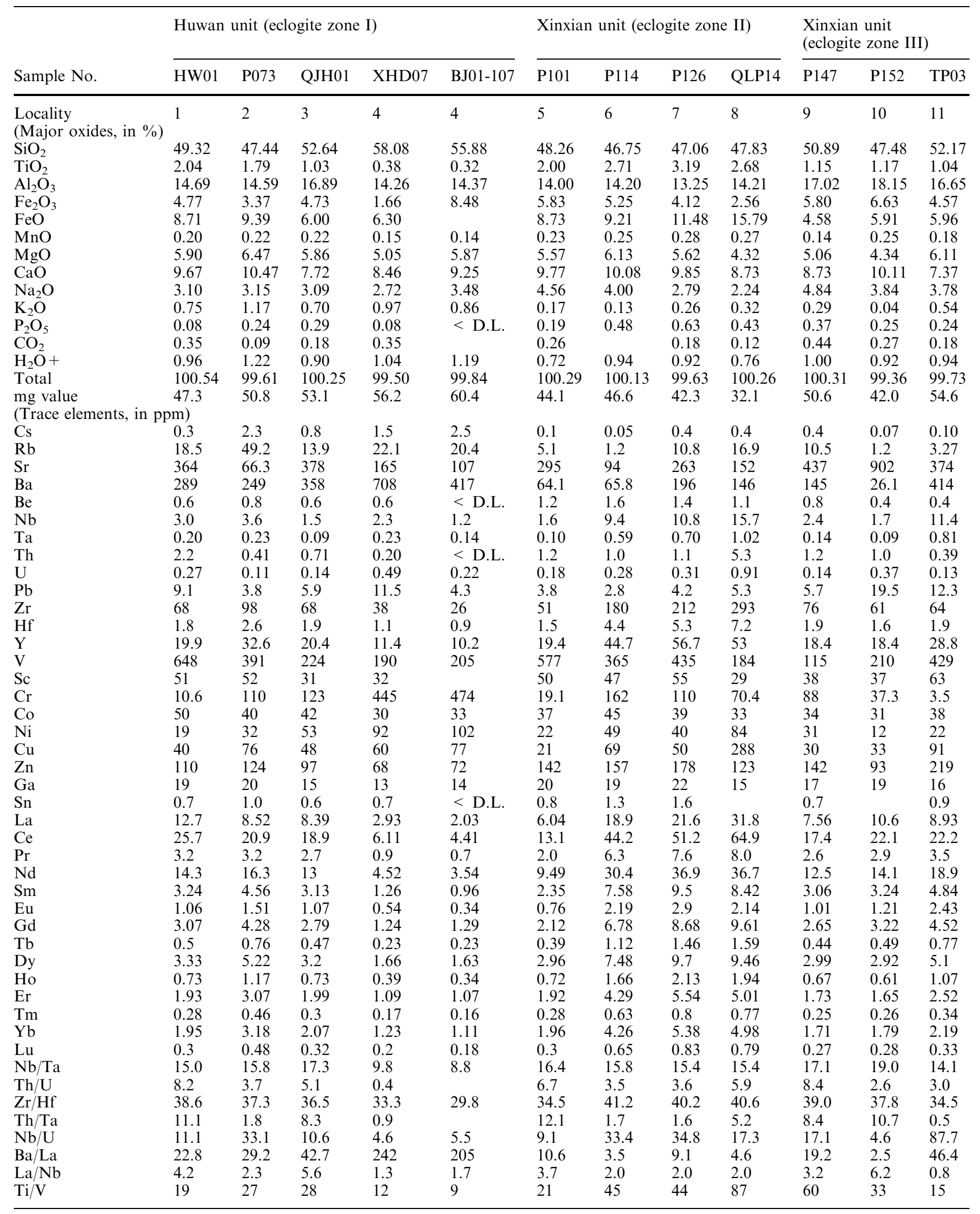

For Locality names: 1. Huwan, 2. Qilongshan, 3. Qianjinhepeng, 4.Xiongdian, 5. Longgushi, 6. Xinwu, 7. Yanjiahe, 8. Sanwu, 9. Ta' ergang, 18. Luwang, 19. Huajiahe, 20. Gaoqiao, 21. Shuaijiahe, 22. Shujiahe, 23. Wangmuguan, 24. Daleiwa, 24. Duanjiagang 


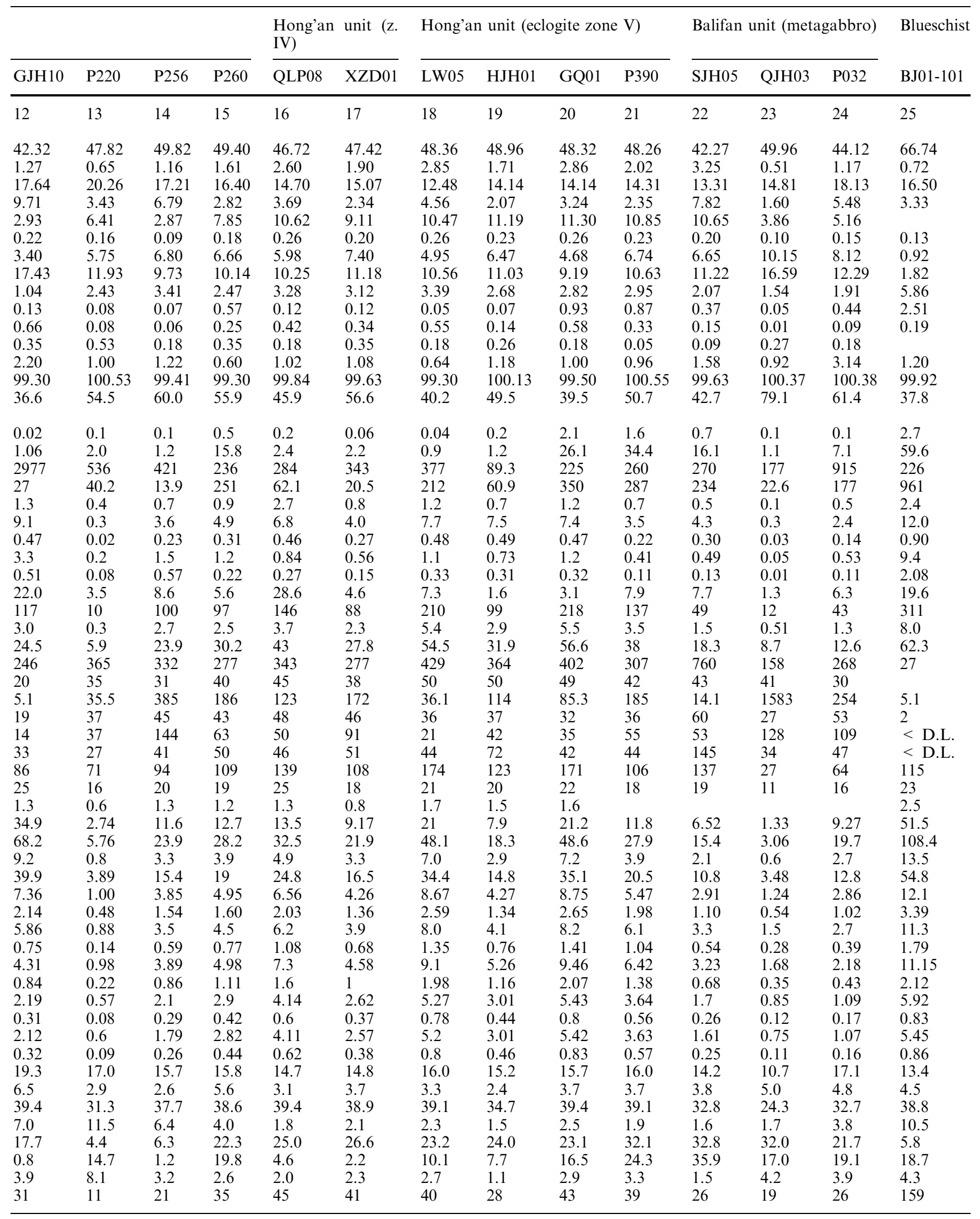

10. Zhugang, 11. Tianpu, 12. Guojiahe, 13. Shejiachong, 14. Minjiachong, 15. Xiongjiazhui, 16. Dongyuemiao, 17. Chaoyangdian, 
Fig. 4 Chondrite-normalized REE distribution patterns of Hong'an eclogites.

Metagabbros from the Balifan Unit are also shown for comparison
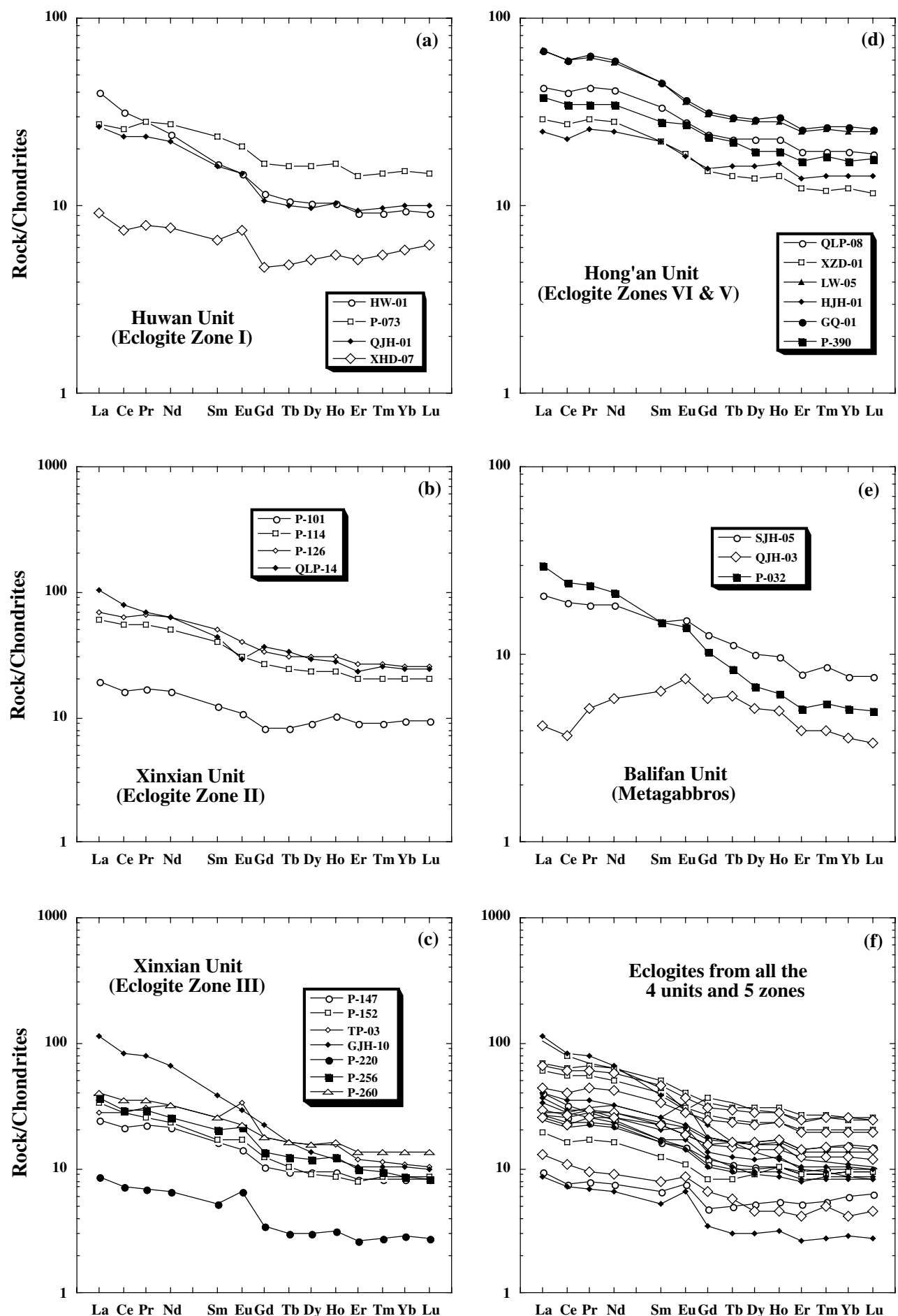

or a portion of rock rich in low $\mathrm{SiO}_{2}$ phases (ex. garnet, epidote, rutile, etc.) from a banded eclogite. Garnetite is a good example of metamorphic differentiation; it cannot be used to discuss the nature of its protolith. It is common to find that the chemical composition of an eclogite cannot be matched by any reasonable magmatic protoliths. In any case, eclogite protoliths cannot be easily classified with the commonly used classification schemes for igneous rocks because most of them, such as
AFM or TAS (Middlemost 1994), involve the use of alkali elements which are known to be mobile in metamorphic processes and are generally depleted during high-grade metamorphism. The TAS classification diagram shown in Fig. 3a serves only for reference. Nevertheless, allowing a maximum depletion of $0.5 \%$ total alkalis as a result of prograde metamorphism, the majority of eclogites from the Hong'an Block are still gabbroic or basaltic in composition. 
Fig. 5 Primitive-mantlenormalized spidergrams of Hong'an eclogites. $\mathrm{Nb}$ is generally depleted with respect to $\mathrm{La}$, attesting to their continental affinity
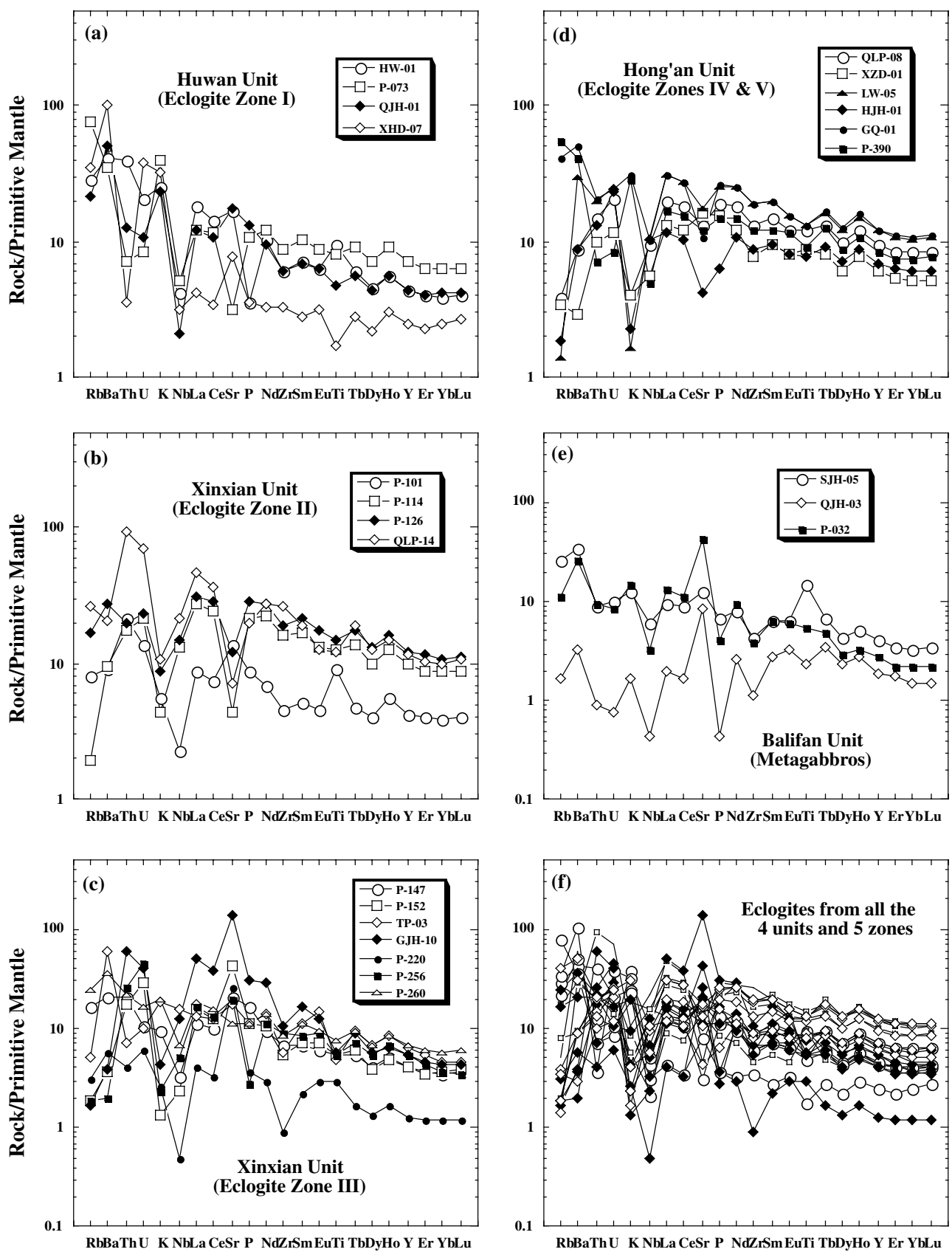

In studies of Precambrian komatiites and other metavolcanic rocks, hydrous and carbonic metasomatism and low-grade metamorphism often pose severe problems for geochemical characterization of these rocks. In order to overcome such problems, Jensen (1976) proposed a cation plot based on the proportions of the cations $\left(\mathrm{Fe}^{2+}+\mathrm{Fe}^{3+}+\mathrm{Ti}\right), \mathrm{Al}$ and $\mathrm{Mg}$, as shown in Figure 3b. The main advantage of this diagram over other classification schemes is that only refractory $(\mathrm{Fe}$, $\mathrm{Ti}, \mathrm{Al})$ and most differentiation-diagnostic ( $\mathrm{Mg})$ elements are used. Fig. 3b shows that all the Hong'an eclogites fall in the basalt fields of the calc-alkaline and tholeiitic series. Note that the eclogites from Eclogite Zone I plot in the andesite or basaltic andesite fields in
Fig. 3a, but not in Fig. 3b. Close examination of five eclogite samples from Xiongdian locality (two from Table 2, and three from Li et al. 2001) reveal that despite their high silica $(55-58 \%)$ and low $\mathrm{TiO}_{2}(0.32-0.38 \%)$ contents, they have $\mathrm{MgO}=5.1-5.9 \%, \mathrm{Cr}=430$ $700 \mathrm{ppm}, \mathrm{Ni}=88-116 \mathrm{ppm}$, and LREE-enriched but less than ten times chondritic REE abundances. These features seem to argue that the protolith of the eclogites was basaltic, but subjected to post-magmatic or synmetamorphic silica-enrichment process, of which the origin is not yet understood. The case is quite similar to the Weihai eclogites. The high silica contents of Weihai eclogites $(54-60 \%)$ are demonstrably of metasomatic origin (Jahn et al. 1996). Their protoliths were originally 
Fig. 6 REE distribution patterns of eclogitic minerals - garnet, omphacite, epidote and amphibole. The analyses were obtained by laserablation ICP-MS
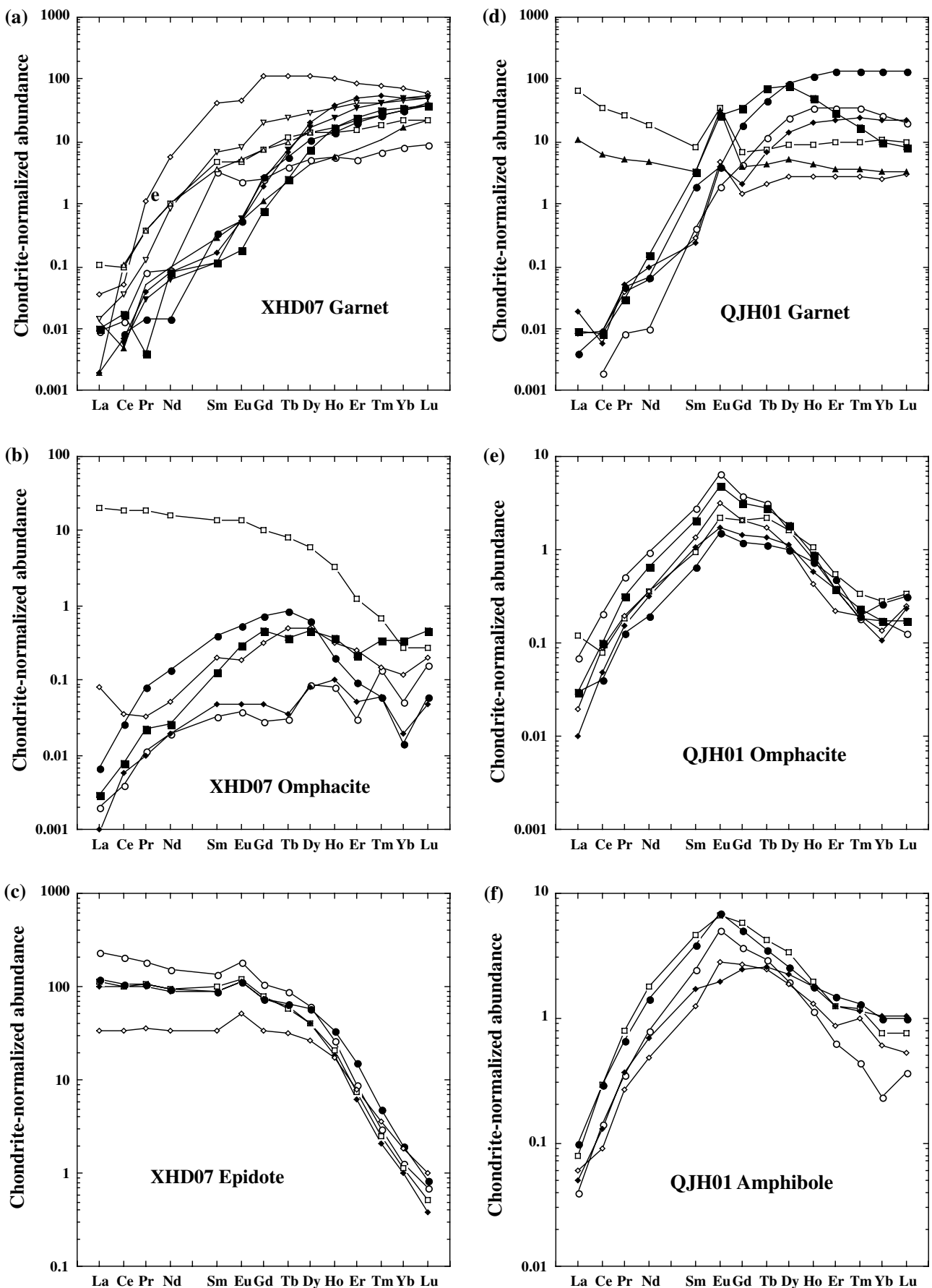

of basaltic composition as inferred from relatively high $\mathrm{MgO}$ (6.3-7.8\%), Ni (73-200 ppm) and $\mathrm{Cr}$ (280$410 \mathrm{ppm})$ contents. Andesitic rocks of island arc or continental margin are renowned for their $\mathrm{Ni}$ (and $\mathrm{Cr}$ ) depletion, but this is not the case for Weihai eclogites. Alternatively, the "andesitic" protolith could be a boninitic magma derived by hydrous melting of metasomatized harzburgite in a back-arc basin (Tatsumi et al. 2002).

Figure 4a-e show REE distribution patterns for eclogites from the four tectonic units and metagabbros from the Balifan Unit. The global feature of all the eclogites is further shown in Fig. 4f. Despite some subtle differences, the REE distribution is characterized by mild fractionation with LREE enrichment. Their abundances vary from 100 to 10 times chondrites in La and all patterns are quasi-parallel. Figure $5 \mathrm{a}-5 \mathrm{f}$ are spidergrams for the same eclogite samples. As expected, $\mathrm{K}$ and $\mathrm{Rb}$ commonly show severe depletion, probably during prograde metamorphism in the eclogite facies. Sr shows both depletion and enrichment with respect to $\mathrm{Ce}$, whereas $\mathrm{Nb}$ (and $\mathrm{Ta}$, not shown) exhibits systematic depletion relative to La. Most of the eclogites display concomitant $\mathrm{Nb}$ and $\mathrm{Zr}$ depletion. All these features are 
Fig. 6 (Contd.)
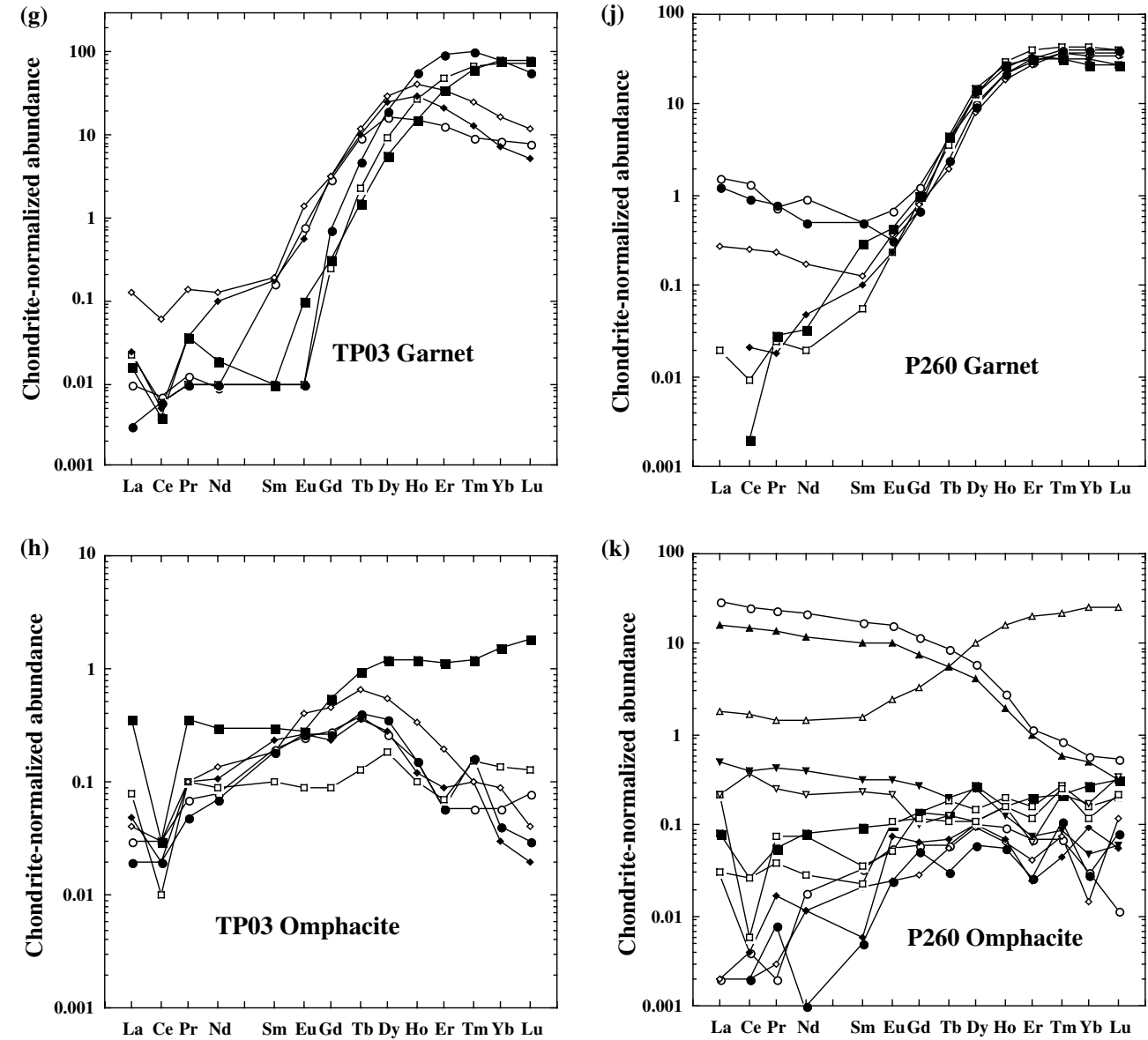

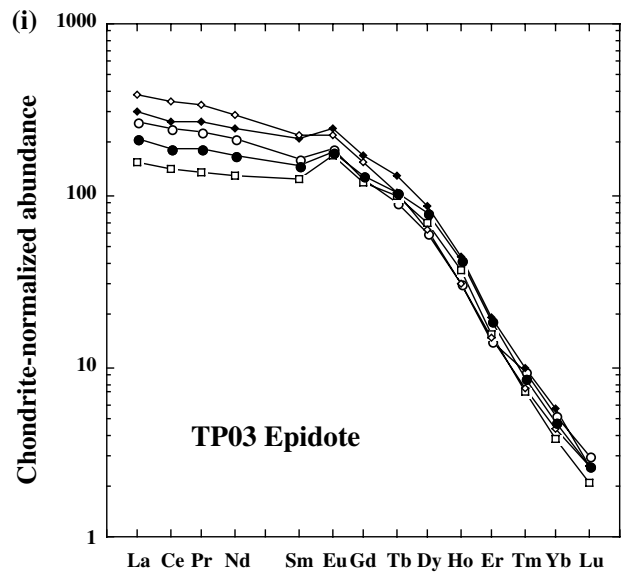

individual phases used for isochron age determination. The analytical data of REE and other trace elements (CMP Data Depository) are graphically shown in Fig. 6a-6q. Note that concentrations less than 0.1 times chondritic abundances are not precise. They can be ignored in the discussion. The principal observations are given below.

Garnet Most garnet analyses display the characteristic patterns with increasing abundance from $\mathrm{La}$ to $\mathrm{Lu}$, or showing maxima at middle REE (e.g., Jahn et al. 2003a). However, this rule does not hold for several samples. Garnets from the Hong'an eclogites generally
The objective of the mineral composition study is to help understand the problem of $\mathrm{Sm}-\mathrm{Nd}$ isotopic equilibrium using information on partition coefficients between

mid-ocean tonic suture.

Chemical compositions of constituent minerals 
Fig. 6 (Contd.)
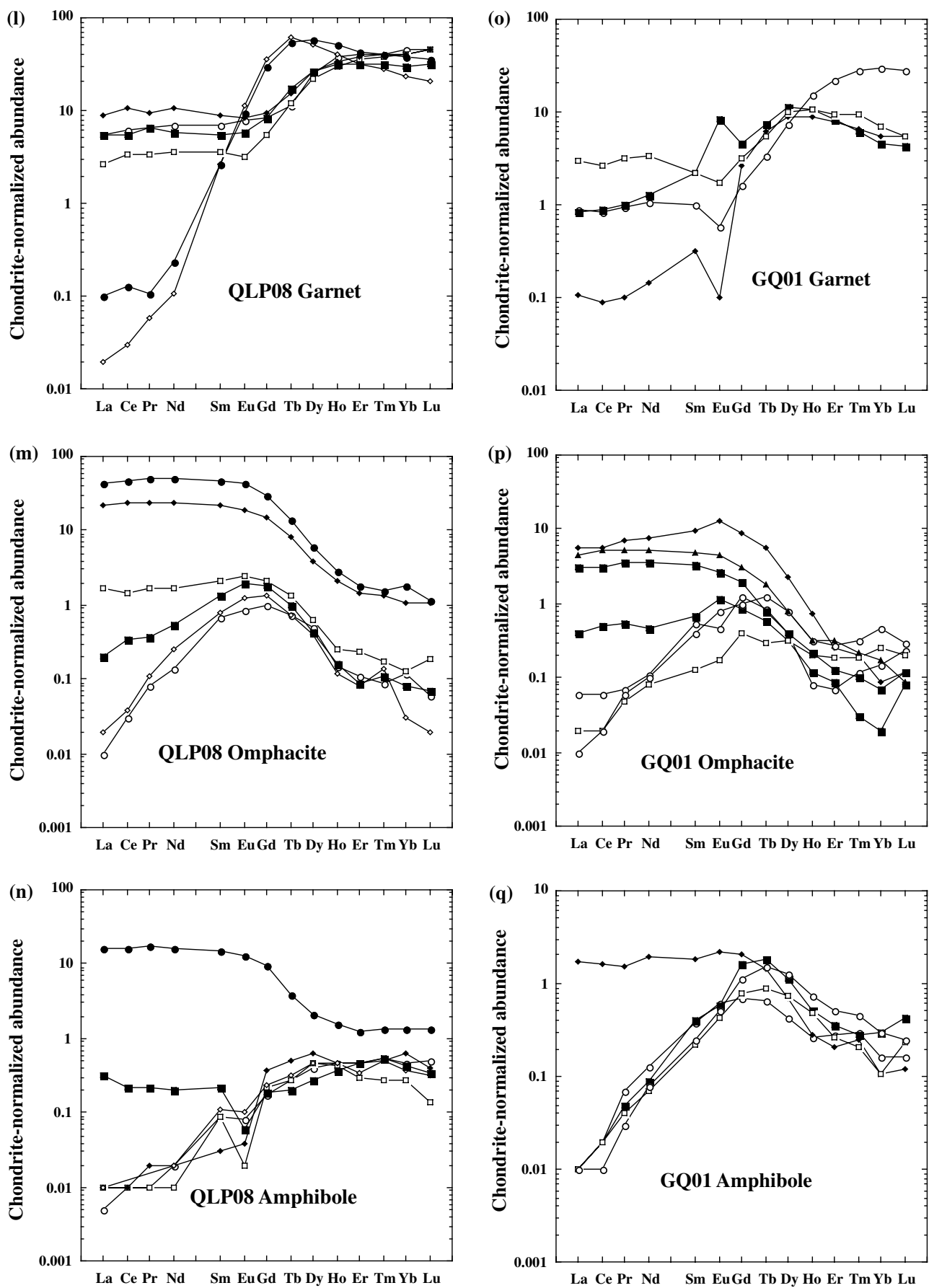

contain large amounts of inclusions. Isotope analyses, to be discussed later, show isotope disequilibrium, which is accompanied in part by nonequilibrated REE partition coefficients between garnet and omphacite. As shown in Appendix, garnet from sample XHD07 has numerous inclusions and exhibits weak compositional zoning. The REE patterns (Fig. 6a) follow the general rule of distribution, but their concentrations vary by one to two orders of magnitude. Garnets from sample QJH01 contain abundant inclusions dominated by amphibole and epidote. Five track analyses show sim- ilar characteristic REE patterns, but two are distinctly different, having much higher LREE abundances with positive Eu anomalies (Fig. 6d). These patterns can be explained as due to a "contamination" of epidote inclusions. Although epidote was not analyzed in this sample, it likely has similar REE concentrations as those from samples XHD07 and TP03. Using the epidote data given here (Figs. 6c, i), the proportion of "contamination" can be estimated to be about 5\%. Garnets from sample TP03 show very low LREE concentrations but rather typical MREE and HREE 
for garnet (Fig. 6g). Garnets of sample P260 are finegrained and contain inclusions of omphacite, epidote and rutile. Their HREE patterns are very uniform but LREE differ by about two orders of magnitude (Fig. 6j). The tracks of higher LREE concentrations are likely due to the presence of omphacite and epidote inclusions. Similarly, garnets from sample QLP08 show two distinct REE patterns (Fig. 61). Two tracks display typical garnet patterns, whereas four others have much higher LREE. The contribution of omphacite or epidote inclusions is clear. Garnets from sample GQ01 is porphyroblast, often contain tiny inclusions including amphibole, epidote, quartz, titanite and rutile. The REE patterns are complex with large variation in LREE and show large Eu anomalies (Fig. 6o) as a result of different inclusions.

Omphacite The literature data show that typical omphacites have hump-shaped REE patterns with maxima at middle REE (Jerde et al. 1993; Snyder et al. 1993; Bocchio et al. 2000; Sassi et al. 2000; Jahn et al. 2003a). Omphacite of sample XHD07 is rather homogeneous, and its REE distributions of this sample generally show the typical omphacite patterns except one with high REE abundances (Fig. 6b). This exceptional pattern is due to "contamination" by epidote inclusion which was not visible during the laser track-scan. The REE data of epidote are illustrated in Fig. 6c. Omphacite of sample QJH01 seldom contains mineral inclusions and is quite homogeneous in composition. The REE abundances are rather uniform showing typical hump-shaped patterns (Fig. 6e). Amphibole from the same sample also possesses nearly identical REE patterns (Fig. 6f), arguing that amphibole was transformed from omphacite and inherited the REE budget entirely from omphacite. This was also observed for the case of the Maowu eclogiteultramafic body from the Dabie terrane (Jahn et al. 2003a). Omphacite from sample TP03 is coarser than garnet and sometimes contains inclusions of small garnet and rutile. Due to their low abundances, the REE data are of poor quality but still show humpshaped patterns (Fig. 6h). However, two patterns require further explanation - the one with high HREE abundances can be explained as due to the presence of garnet inclusion; whereas the other with higher LREE probably indicates inclusions of epidote, whose REE patterns are shown in Fig. 6i. The similar features are observed in omphacite of sample P260. The omphacite has very low REE abundances ( $<1.0$ times chondrite); their poor analyses do not clearly show typical omphacite patterns (Fig. 6k). However, the one with the highest HREE is clearly due to garnet because the track contains very high $\mathrm{Al}$ and $\mathrm{Fe}$, and low $\mathrm{Sr}$ concentration (13 ppm), whereas the two with high LREE are a result of epidote inclusion. Omphacite from sample QLP08 shows a large variation in both LREE and HREE distribution (Fig. $6 \mathrm{~m}$ ). The lowest abundances with hump-shaped patterns are of inclusion-free omphacite, the others can be explained as due to variable contributions from epidote inclusions. Omphacite from sample GQ01 has much in common with that of QLP08 (Fig. 6p). Amphibole also shows similar hump-shaped REE patterns with one exception.

Epidote Epidotes from two samples (XHD07 and TP03) show similar REE patterns (Figs. 6c, i), with high and gently sloped LREE (100-400 times, except one) and sharply declined HREE towards Lu; all of them show positive Eu anomalies. The average $(\mathrm{La} / \mathrm{Lu})_{\mathrm{N}}$ ratio is about 100 .

Summary on mineral REE abundances $\mathrm{Sm}$ and $\mathrm{Nd}$ concentrations in garnet, clinopyroxene, orthopyroxene and amphibole from a variety of rocks have been compiled from the literature data (Jahn et al. 2003b). More than $70 \%$ of garnets from eclogites have $\mathrm{Nd}$ concentrations less than $1 \mathrm{ppm}$, and their $\mathrm{Sm} / \mathrm{Nd}$ ratios very from 0.5 to $>10$. A small number of garnets $(7 / 140)$ have $\mathrm{Sm} / \mathrm{Nd}$ ratios less than the chondritic value of ca. 0.325 ; most of these have exceptionally high $\mathrm{Nd}(5-$ $23 \mathrm{ppm}$ ), suggesting that the garnets contain significant amounts of LREE-rich inclusions, such as monazite, zoisite/epidote or apatite. "Clean" garnets, like those from the Bixiling complex of the Dabie terrane, tend to have low $\mathrm{Nd}$ concentrations ( $\leq 0.5 \mathrm{ppm}$ ) and high $\mathrm{Sm} /$ $\mathrm{Nd}$ ratios (Jahn et al. 2003b). With respect to omphacites, $\mathrm{Nd}$ concentrations vary from $0.1 \mathrm{ppm}$ to $40 \mathrm{ppm}$, with ca. $70 \%$ less than $6 \mathrm{ppm}$. Sm/Nd ratios generally fall in the range of $0.2-0.5$, with only few $(7 / 153)$ exceeding 1.0.

Figure 7 shows plots of $\mathrm{Sm} / \mathrm{Nd}$ vs [Nd] for garnet and omphacite from this study, with the ranges of the same minerals from the Maowu Complex (Jahn et al. 2003a). The $\mathrm{Sm}-\mathrm{Nd}$ isotope systems in the Maowu rocks produced correct Triassic ages, hence are considered to have reached isotope equilibrium. The garnet and omphacite data of Maowu eclogites and pyroxenites fall in two distinct and tight areas. Garnet has a range of $\mathrm{Nd}$ concentrations from about 0.1 to $1 \mathrm{ppm}$, and $\mathrm{Sm} / \mathrm{Nd}$ ratios from 1 to 10 . Such ranges appear to be "normal". By contrast, garnets from the six rocks from the Hong'an Block for isotope analyses show $\mathrm{Nd}$ concentrations and $\mathrm{Sm} / \mathrm{Nd}$ ratios quite variable, and many of the ratios less than 0.3 . This is very unusual when they are compared with the compiled data described above. Omphacite of the Maowu eclogites-pyroxenites has a small range of $\mathrm{Sm} / \mathrm{Nd} \mathrm{ra}$ tios about 0.4 (Fig. 7) despite of a large range of $\mathrm{Nd}$ concentrations from $0.7 \mathrm{ppm}$ to $30 \mathrm{ppm}$. The Hong'an omphacites have $\mathrm{Sm} / \mathrm{Nd}$ ratios much more variable, from 0.15 (sample P260) to 2 (samples XHD07 and GQ01), and nearly a quarter (11/43) exceeding 1 . The unusual concentrations and $\mathrm{Sm} / \mathrm{Nd}$ ratios in the Hong'an minerals reflect the effect of inclusions and the coexisting minerals are possibly out of chemical equilibrium. 


\section{$\mathbf{R b}-\mathbf{S r}$ and $\mathbf{S m}-\mathbf{N d}$ isotope analyses}

The results of $\mathrm{Rb}-\mathrm{Sr}$ and $\mathrm{Sm}-\mathrm{Nd}$ isotopic analyses on minerals separated from six basaltic eclogites, one glaucophane schist and a marble are presented in Table 3 and further illustrated in Figs. 8,9,10,11,12,13,14 and 15 . The most striking observation is that none of the $\mathrm{Sm}-\mathrm{Nd}$ isotope systems provide useful age information, and half of the $\mathrm{Rb}-\mathrm{Sr}$ systems are equally disturbed. The apparently undisturbed cases are represented by the phengite-based $\mathrm{Rb}-\mathrm{Sr}$ isochrons of $212 \pm 7$ (2sigma) Ma for sample TP03 (Fig. 10), $225 \pm 34 \mathrm{Ma}$ for QLP08

Fig. $7 \mathrm{Sm} / \mathrm{Nd}$ versus $\mathrm{Nd}$ plots for garnet and omphacite from the Hong'an eclogites. The data of the chemically and isotopically equilibrated Maowu complex are shown for reference. The Hong'an data often show wide scatter and incorrect $\mathrm{Sm} / \mathrm{Nd}$ ratios. The data obtained by the isotope dilution (ID) method using whole-grain dissolution are very different from those obtained by LA-ICP-MS. This clearly indicates the contribution of REE-rich inclusions such as epidote, apatite, or other phases; many of these phases were not analyzed by LA-ICP-MS
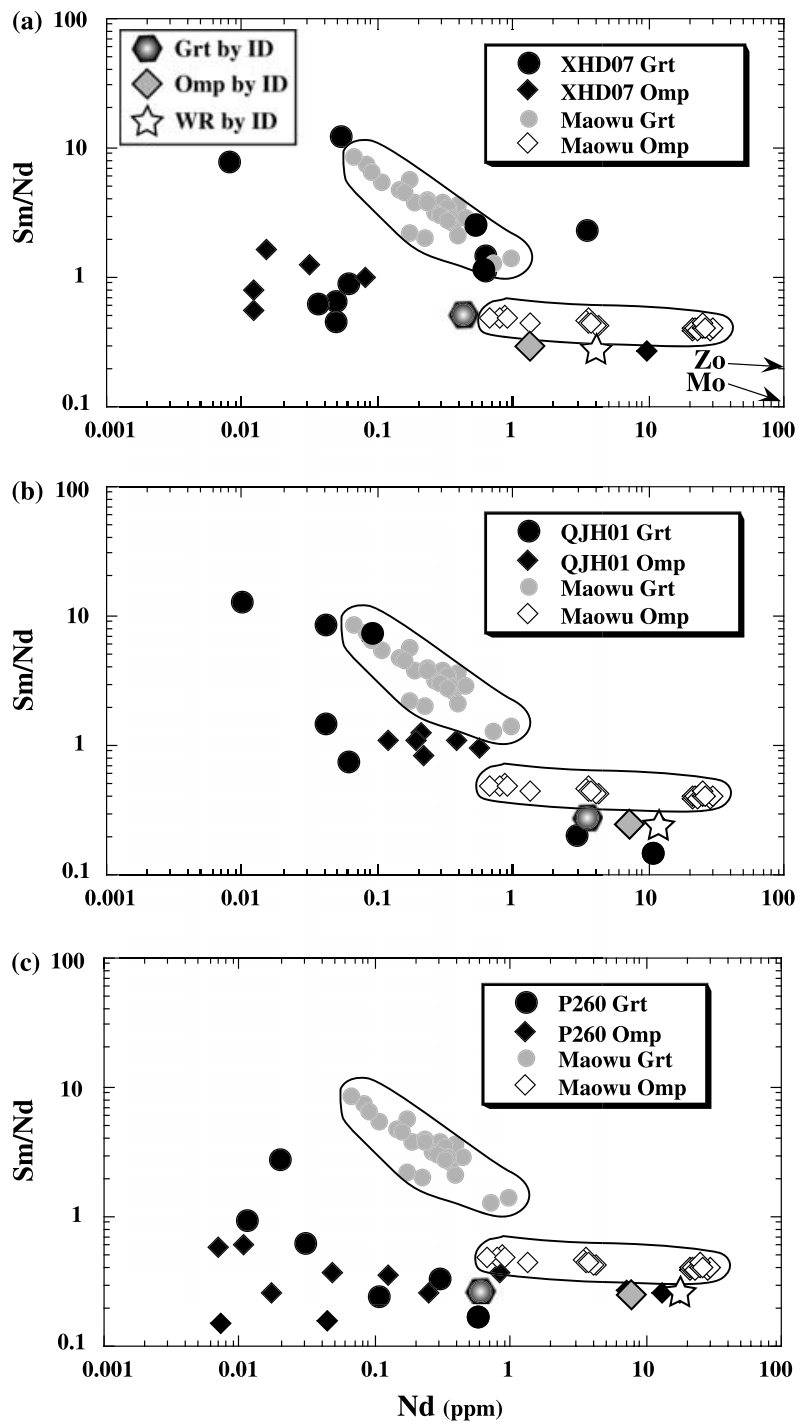

(Fig. 12), 216 $\pm 10 \mathrm{Ma}$ for glaucophane schist (sample BJ01-101; Fig. 14), and 210 \pm 4 Ma for Marble Hill (sample BJ01-115; Fig. 15). The ages of 225-210 Ma are comparable with ${ }^{40} \mathrm{Ar} /{ }^{39} \mathrm{Ar}$ ages obtained on a variety of rock types from the Hong'an Block (Eide et al. 1994; Webb et al. 1999, 2001; Hacker et al. 2000). They can be interpreted as cooling ages. The meaning of the younger age of $172 \pm 23 \mathrm{Ma}$ for sample P260 (Fig. 11) is not clear, but is possibly related to retrograde amphibolite facies metamorphism. Note also that the pattern of $\mathrm{Rb}-$ $\mathrm{Sr}$ isotope disequilibrium appears to be random and is independent of the petrological temperatures.

In the $\mathrm{Sm}-\mathrm{Nd}$ isotope systems, negative isochron relationship is observed for two eclogites: one from the coesite-bearing unit (P260; Fig. 11), and the other from cold eclogite unit (QLP08; Fig. 12). Grt-Omp tie-lines yielded highly variable "isochron ages" of $260 \mathrm{Ma}$ (XHD07 and BJ01-107), $420 \mathrm{Ma}$ (QJH01), 1,057 Ma (TP03), and $182 \mathrm{Ma}$ (GQ01), whereas Grt-WR tie-lines gave 346, 250, 820, and $218 \mathrm{Ma}$, respectively. Quite
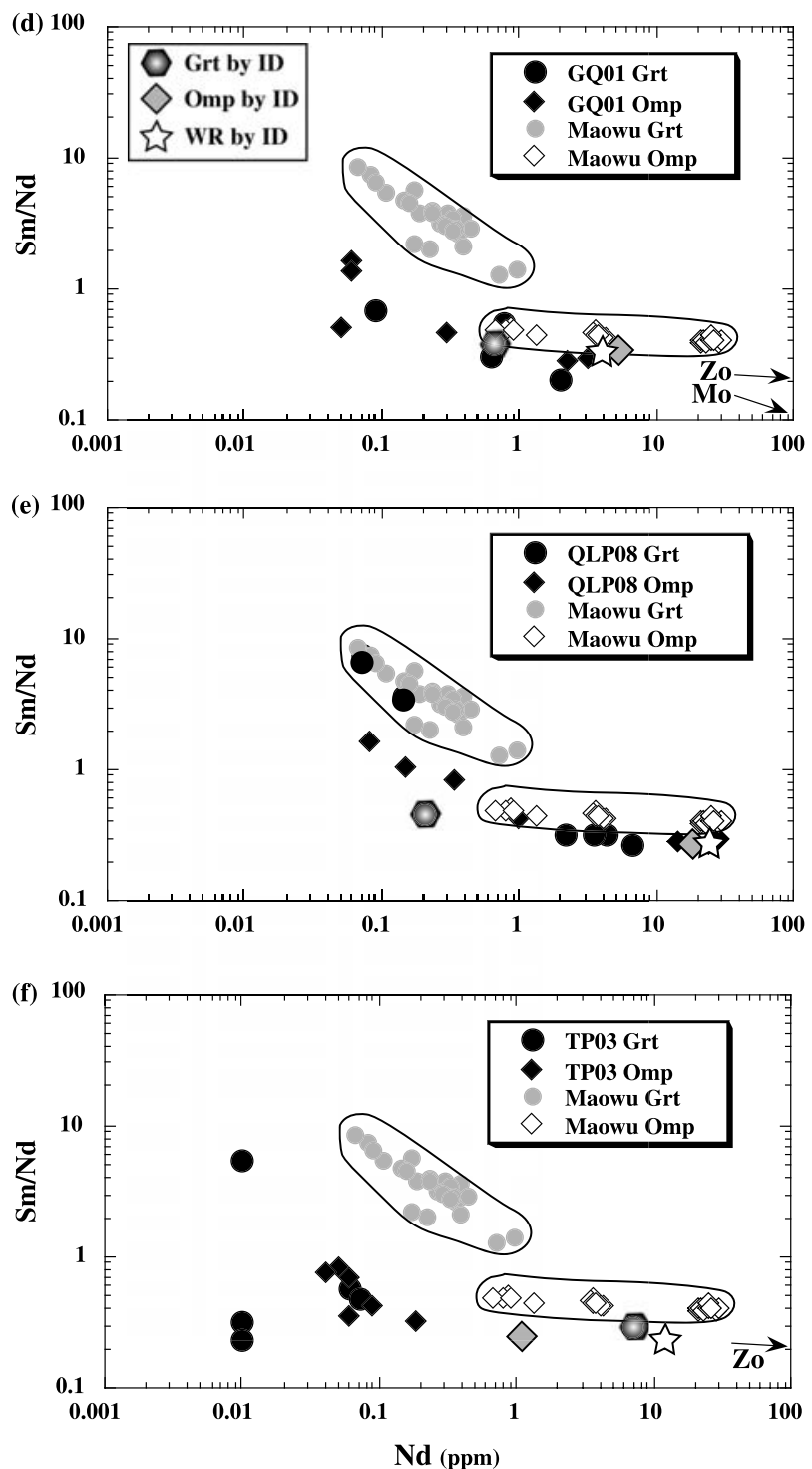


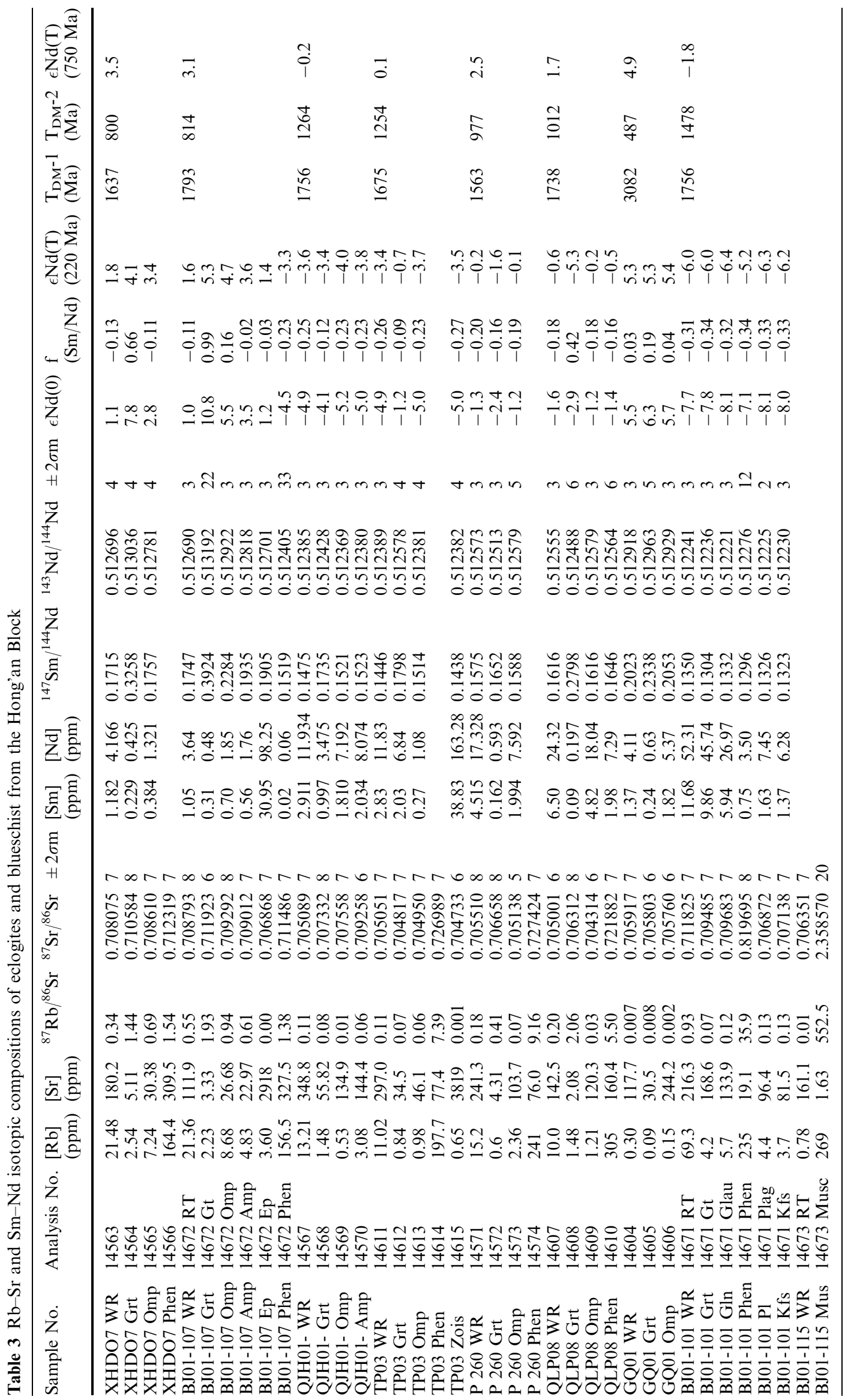



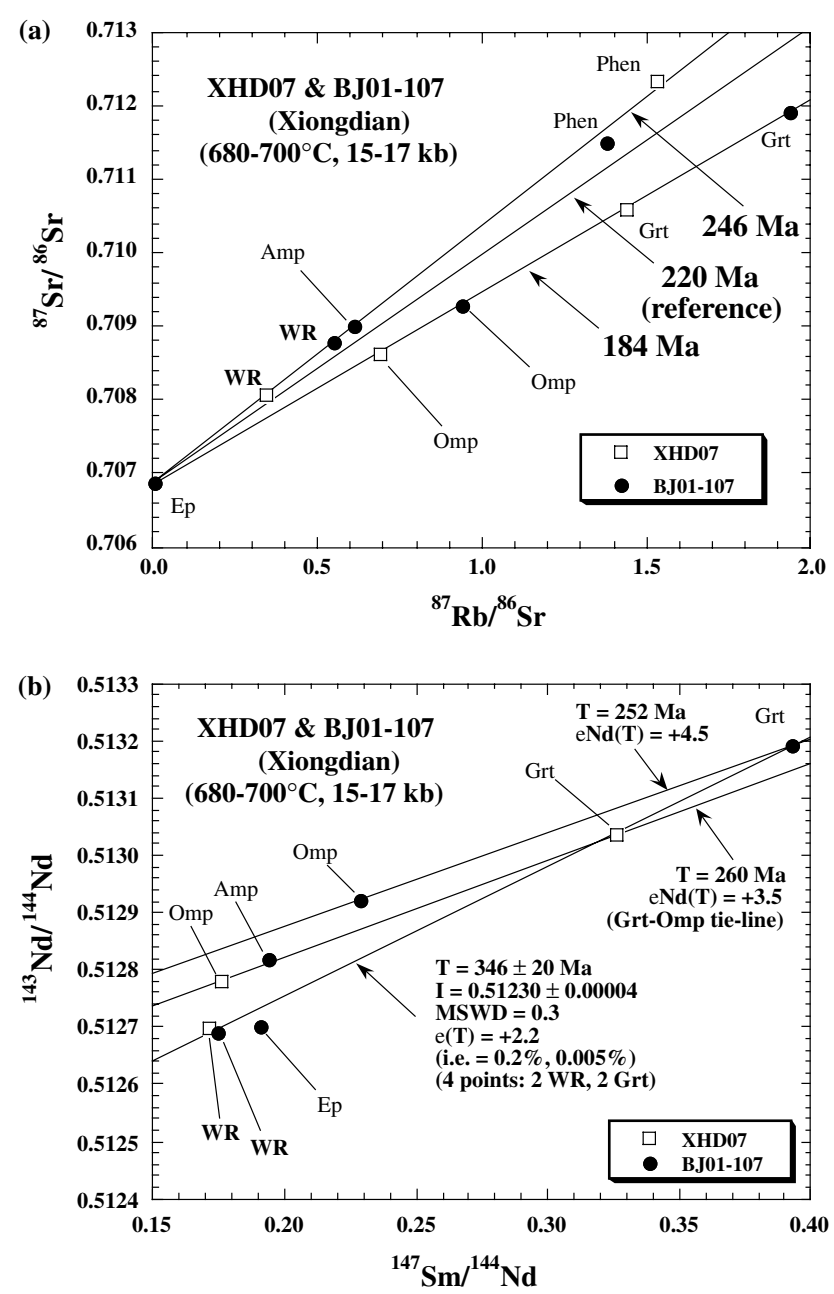

Fig. $8 \mathrm{Rb}-\mathrm{Sr}$ and $\mathrm{Sm}-\mathrm{Nd}$ isochron diagrams for sample XHD07 and $\mathrm{BJ} 01-107$

visibly, Carboniferous to Silurian ages, as shown to exist by some workers, can be reproduced from such unequilibrated isotopic systems. In addition, WR data points are always found to lie outside the Grt-Omp tielines. This indicates that isotopic compositions of coexisting minerals were not homogenized during metamorphism and that WR must be mass-balanced by nonanalyzed accessory phases. The ${ }^{147} \mathrm{Sm} /{ }^{144} \mathrm{Nd}$ ratios of the analyzed garnets range from 0.17 to 0.39 . This is much lower than the "normal "garnet values of 0.5 to 2.0. Besides, two garnets contain high $\mathrm{Nd}$ concentrations (3.5 and $6.8 \mathrm{ppm}$ ), which likely resulted from the presence of LREE-rich microinclusions (e.g., epidote and monazite). In fact, the laser track analysis described earlier shows that some pure garnet domains could have very high $\mathrm{Sm} / \mathrm{Nd}$ ratios (Fig. 7). However, such pure domains could not be separately analyzed in the isotope dilution analysis.

The above observations raise a serious question about the validity of the published $\mathrm{Sm}-\mathrm{Nd}$ mineral isochron ages on the Hong'an Block. Such unequilibrated $\mathrm{Sm}-\mathrm{Nd}$ systems are rarely encountered for
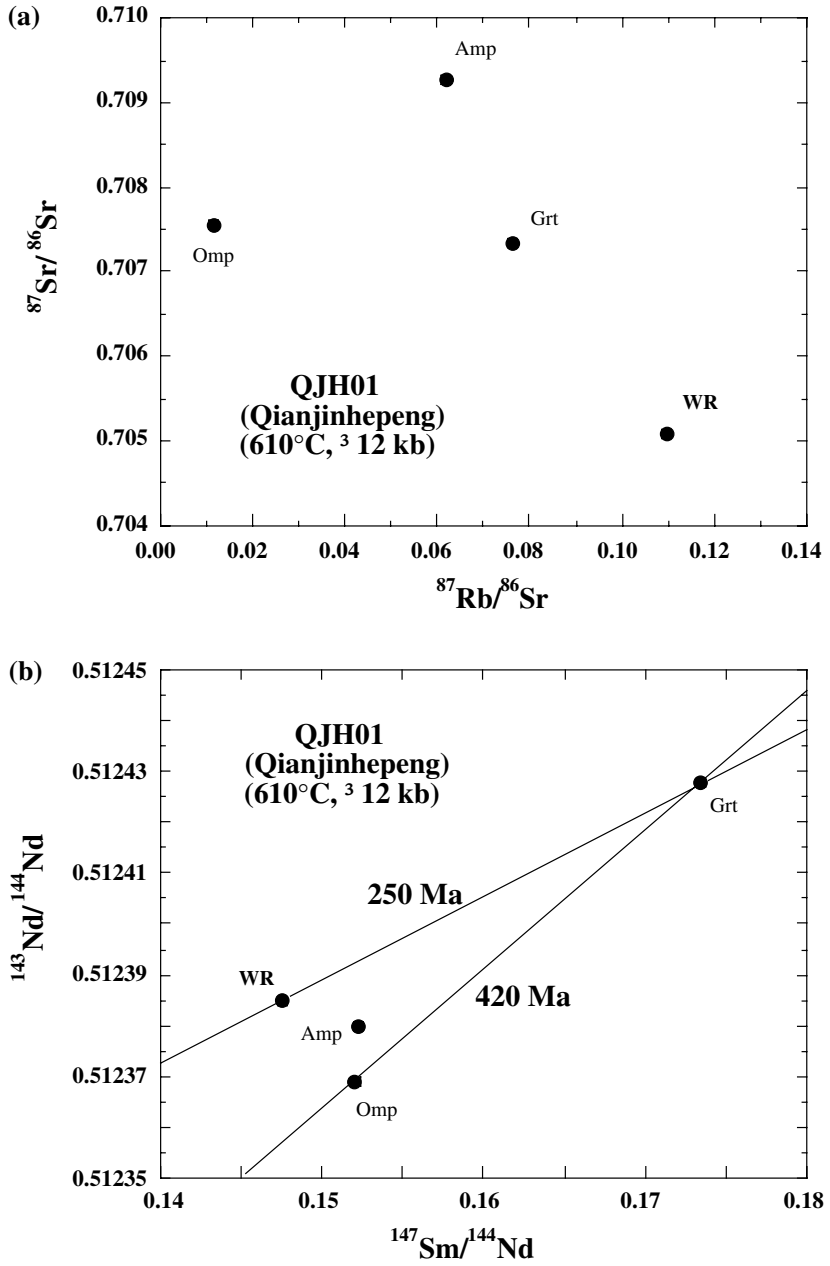

Fig. $9 \mathrm{Rb}-\mathrm{Sr}$ and $\mathrm{Sm}-\mathrm{Nd}$ isochron diagrams for sample QJH01

eclogites from the higher-temperature Dabie and Sulu terranes (e.g. Li et al., 1993, 2000; Chavagnac and Jahn 1996; Chavagnac et al. 2001; Jahn et al. 2003a) except two localities (Yakou and Yangkou) of the Sulu terrane (Zheng et al. 2002) and a retrograded clinopyroxene garnetite from northeastern Dabie (Xie et al. 2004). In the Hong'an Block, the Xiongdian eclogite (locality identical to our samples XHD07 and BJ01-107; $31^{\circ} 45.14^{\prime} \mathrm{N}, 114^{\circ} 28.50^{\prime} \mathrm{E}$ ) has been subjected to several zircon $\mathrm{U}-\mathrm{Pb}$ and garnet $\mathrm{Sm}-\mathrm{Nd}$ geochronological investigations. However, all the published results failed to produce consistent and interpretable ages. Clearly, the isotopic systems $(\mathrm{Sm}-\mathrm{Nd}$ and $\mathrm{U}-\mathrm{Pb})$ are largely out of equilibrium in these "cold eclogites", and some of the apparent concordant zircon dates of 300 to $450 \mathrm{Ma}$ could have been produced by partial recrystallization (Pidgeon 1992; Pidgeon et al. 1998; Hoskin and Black 2000; Li 2003).

\section{Failure of producing meaningful ages}

Meaningful $\mathrm{Sm}-\mathrm{Nd}$ and $\mathrm{Rb}-\mathrm{Sr}$ isochron ages have been obtained for the Bixiling and Maowu Complexes from 

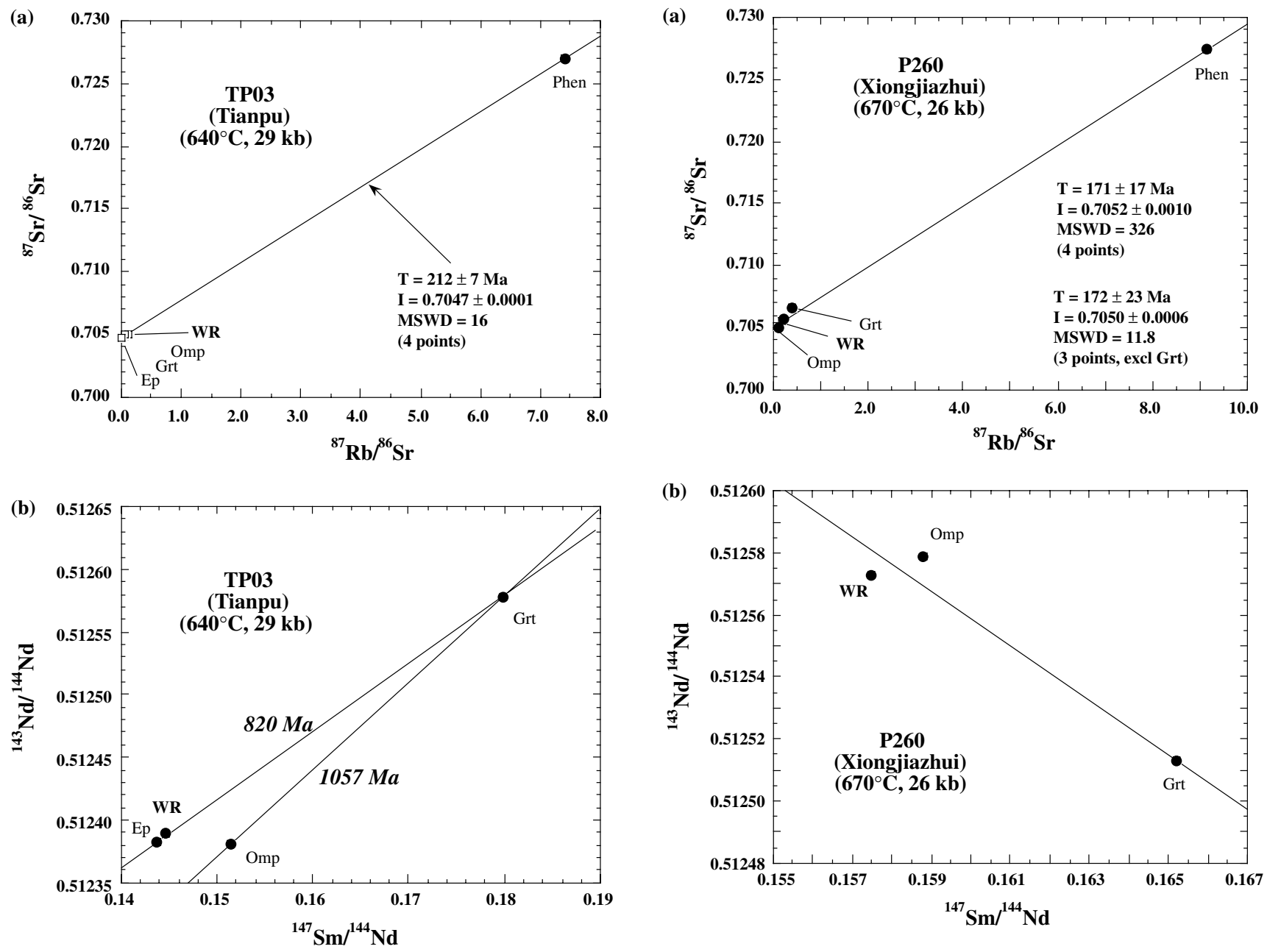

Fig. $10 \mathrm{Rb}-\mathrm{Sr}$ and $\mathrm{Sm}-\mathrm{Nd}$ isochron diagrams for sample TP03

the Dabie terrane (Chavagnac and Jahn 1996; Jahn et al. 2003a). The metamorphic ages of ca. $220 \mathrm{Ma}$ for the Bixiling Complex are in perfect agreement with the SHRIMP U-Pb zircon ages obtained by Cheng et al. (2000) and Li (2003). The Maowu eclogites and pyroxenites appear to have recorded slightly older ages at ca. $230 \mathrm{Ma}$, and the results are also consistent with those obtained by the conventional (Rowley et al. 1997) as well as SIMS zircon analyses (CAMECA ims-1270, Ayers et al. 2002). Moreover, meaningful Sm-Nd and $\mathrm{Rb}-\mathrm{Sr}$ isochron ages of ca. $620 \mathrm{Ma}$ have been obtained for the Pan-African coesite-bearing eclogites from Mali (Jahn et al. 2001). The Mali eclogites are the oldest UHP eclogites identified so far. Note that all the rocks have been recrystallized in UHP metamorphic conditions with temperatures well over $700^{\circ} \mathrm{C}$.

Excess Ar in phengitic mica of HP-UHP rocks have been frequently documented (e.g., Li et al. 1994, 2000; Hacker et al. 2000; Jahn et al. 2001). Similarly, aberrant $\mathrm{Sm}-\mathrm{Nd}$ mineral isochron ages have also been obtained, particularly for "low temperature" ( $\left.\leq 600^{\circ} \mathrm{C}\right) \mathrm{HP}-$ UHP metamorphic rocks. The most notorious examples

Fig. $11 \mathrm{Rb}-\mathrm{Sr}$ and $\mathrm{Sm}-\mathrm{Nd}$ isochron diagrams for sample P260

are from the Alps and the Himalayas (e.g., Luais et al. 2001; Thöni 2002). The Hong'an Block adds a new example to the list. The main cause for this chronometric problem is the lack of isotopic equilibrium between garnet and its coexisting minerals. Garnet is the major Al-carrying phase in eclogite and is probably transformed mainly from plagioclase, whereas omphacite is derived from magmatic pyroxenes. However, the detail of phase reactions leading to the formation of these two minerals in such metamorphic conditions could be more complicated.

Granting the simplified case, during the "low temperature" metamorphic transformation from plagioclase to garnet, the reconstitution of lattice-forming major elements may not be closely followed by REEs due to their smaller diffusion coefficients. Isotopic equilibrium would not be expected to occur when chemical equilibrium is not reached. In numerous cases, garnet crystals show major element zonation of prograde metamorphism (e.g., Liu et al. 2004a). This is clear evidence for nonequilibrated growth zones. In this case, trace element and isotopic equilibrium is probably out of question. 

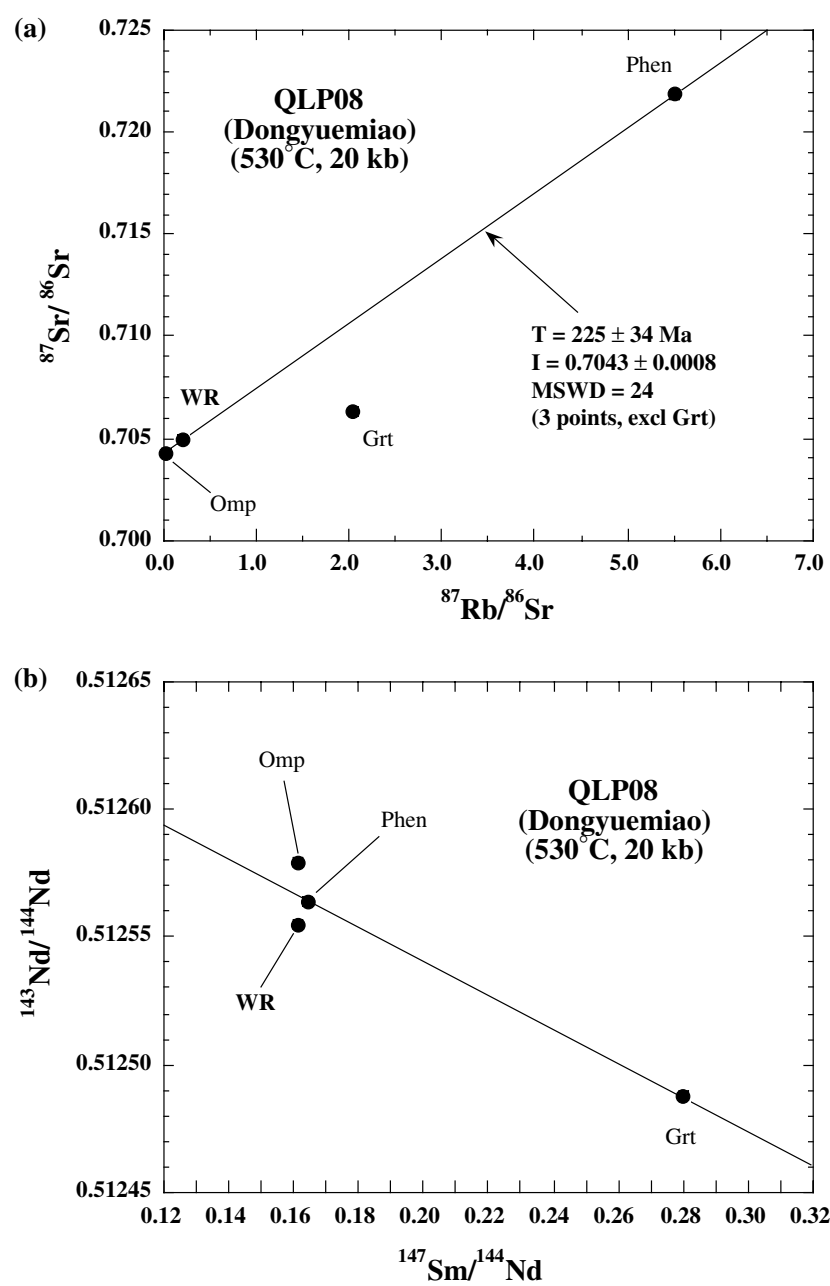

Fig. $12 \mathrm{Rb}-\mathrm{Sr}$ and $\mathrm{Sm}-\mathrm{Nd}$ isochron diagrams for sample QLP08

The phenomenon of $\mathrm{Sm}-\mathrm{Nd}$ isotopic equilibrium/ disequilibrium is most dependent on the prime factor of temperature, but little on pressure. Other factors, such as the intensity of deformation or crystal-fracturing in garnet (Whitney 1996), remains to be evaluated. The temperature effect leads to the concept of blocking temperature $\left(T_{\mathrm{B}}\right.$; Dodson 1973), which does not have a unique value but is also influenced by several other factors including mineral grain-size, rate of cooling, duration of metamorphic reaction at temperature higher than $T_{\mathrm{B}}$, presence of fluid phase and its composition, and penetrative deformation (e.g., Thöni 2002). The literature data indicate that $T_{\mathrm{B}}$ values for the garnet $\mathrm{Sm}-$ $\mathrm{Nd}$ isotope chronometer range from as high as $850^{\circ} \mathrm{C}$ for fast-cooling terranes to as low as $600-650^{\circ} \mathrm{C}$ for slowcooling terranes (Humphries and Cliff 1982; Jagoutz 1988; Mezger et al. 1992; Burton et al. 1995; Zhou and Hensen 1995; Günther and Jagoutz 1997; Thöni 2002). Garnet out of isotopic equilibrium is often accompanied by nonequilibrated trace element patterns. In some cases, $\mathrm{Sm} / \mathrm{Nd}$ ratios of garnets are so unusual that they are smaller than that of whole-rock samples; whereas in others, all coexisting minerals show little difference in
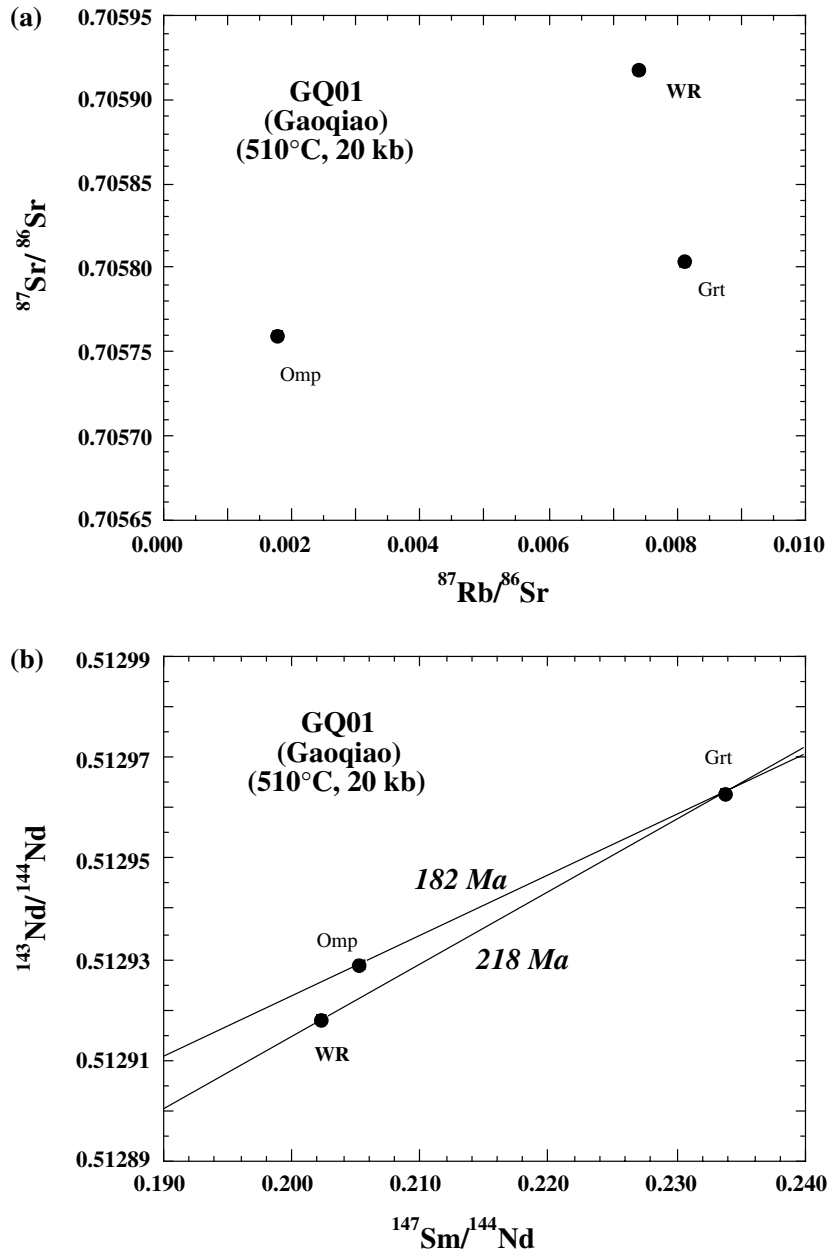

Fig. $13 \mathrm{Rb}-\mathrm{Sr}$ and $\mathrm{Sm}-\mathrm{Nd}$ isochron diagrams for sample GQ01

$\mathrm{Sm} / \mathrm{Nd}$ ratios so they form a cluster in an isochron diagram, as shown in the glaucophane schist sample (Fig. 14). In still other cases, garnet and omphacite may have established equilibrium $\mathrm{Sm} / \mathrm{Nd}$ partition coefficients but not their $\mathrm{Nd}$ isotopic compositions, thus resulting in a negative slope "futurechron" relationship (Figs. 11, 12). This has been found in eclogites of Tso Morari of the Himalayas and the Sesia zone of western Alps (Duchêne et al. 1997; de Sigoyer et al. 2000; Luais et al. 2001).

Porphyroblastic garnets often contain mineral inclusions. In addition to coesite, many of them are REE-rich phases, such as monazite, zoisite, epidote, allanite, titanite, apatite, zircon, etc. Except zircon, all these phases are highly enriched in LREE with very low $\mathrm{Sm} / \mathrm{Nd}$ ratios. Thus, a tiny amount of such inclusions could significantly lower $\mathrm{Sm} / \mathrm{Nd}$ ratio in garnet, hence, affecting isochron construction based on Grt-Cpx-WR and other minerals. Inclusions must have undergone the same metamorphic $P-T$ path as garnet, clinopyroxene and other major phases. If the metamorphic temperature exceeds the $T_{\mathrm{B}}$ of the inclusions (moderate $T_{\mathrm{B}}$ minerals, such as epidote, apatite and titanite), the $\mathrm{Nd}$ isotopic 
(a)

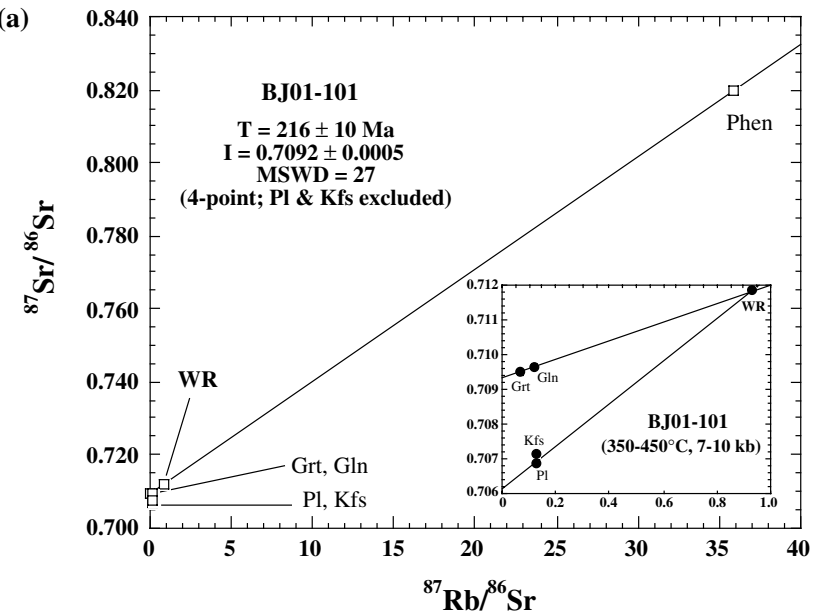

(b)

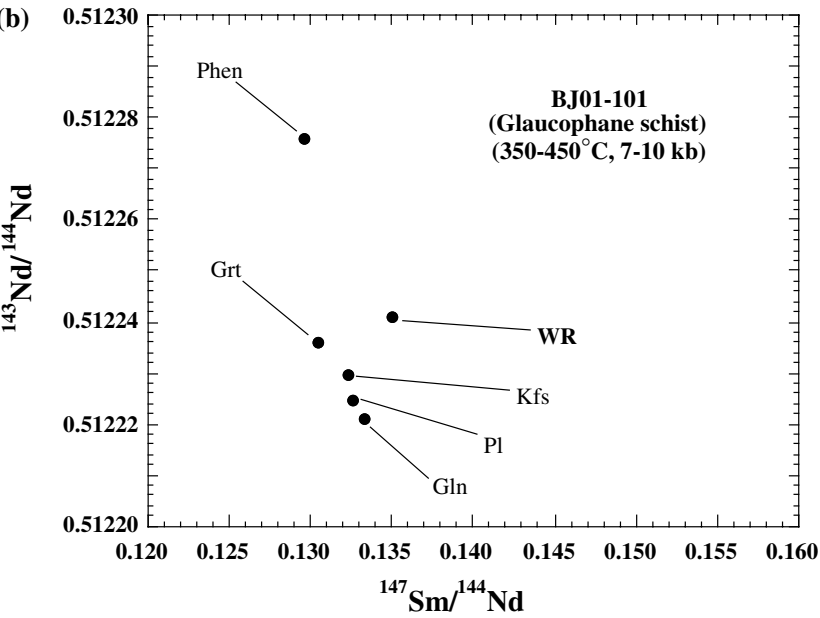

Fig. $14 \mathrm{Rb}-\mathrm{Sr}$ and $\mathrm{Sm}-\mathrm{Nd}$ isochron diagrams for sample BJ01-101 (glaucophane schist)

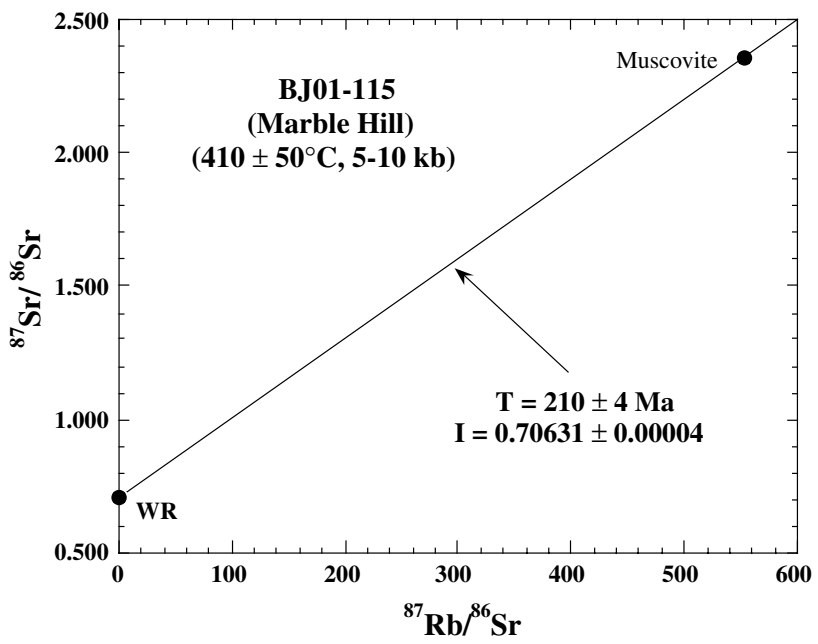

Fig. $15 \mathrm{Rb}-\mathrm{Sr}$ and $\mathrm{Sm}-\mathrm{Nd}$ isochron diagrams for sample BJ01-115 (marble) compositions of inclusions could be expected to attain isotopic equilibrium with host garnet. In this case, a correct isochron age may be obtained, but the range of data spread would be reduced, and hence the statistical error in age increased. This has been most frequently observed in the "high-temperature" eclogites of the Dabie and Sulu terranes. On the other hand, mineral inclusions of very high $T_{\mathrm{B}}$ (e.g., zircon and monazite) may not be reset isotopically to keep pace with growing garnet. In this case, it may produce a disequilibrated isochron relationship.

In conclusion, the failure of producing a correct $\mathrm{Sm}-$ $\mathrm{Nd}$ isochron age is due to isotope disequilibrium between garnet and its coexisting minerals, including inclusions. The disequilibrium results from two distinct processes: (1) garnet preserves the isotopic composition of its precursor mineral (plagioclase) because the rate of $\mathrm{Nd}$ isotope exchange is more sluggish than that of the chemical and mineral phase reconstitution; (2) garnet contains high-temperature refractory LREE-rich inclusions, which have not been isotopically re-equilibrated with host garnet, though the garnet may have attained equilibrium with coexisting clinopyroxene and other principal phases. The above disequilibrium does not include the open system behavior occurring during retrograde metamorphism with strong influence of hydrothermal activity, as demonstrated by Xie et al. (2004).

\section{Oxygen isotope information}

Oxygen isotopic compositions of eclogite minerals have generally attained isotope equilibrium at their eclogite facies temperatures (e.g., Zheng et el. 2002). The equilibrium is indicated by the fractionation between individual minerals, as expressed by $\Delta$ values $\left(\delta^{18} \mathrm{O}_{\mathrm{A}}-\right.$ $\left.\delta^{18} \mathrm{O}_{\mathrm{B}}\right)$. The sequence of ${ }^{18} \mathrm{O}$ enrichment in eclogite minerals is consistent with the empirically, experimentally and theoretically determined values for equilibrium fractionation (Zheng et al. 1998 and references therein). In fact, calculated oxygen isotope temperatures have been shown to be quite comparable with petrological temperatures (Yui et al. 1995; Zheng et al. 1998, 1999).

The analytical data of oxygen isotope compositions are given in Table 4. Figure 16 illustrates oxygen isotope fractionation values $\left(\Delta^{18} \mathrm{O}\right)$ between garnet and omphacite versus $\delta^{18} \mathrm{O}$ of garnet in eclogites from numerous localities including the Hong'an Block. The range of isotope equilibrium fractionation at eclogitic temperatures $\left(\Delta^{18} \mathrm{O}=0-2 \%\right)$ is shown by grey area for reference. Garnet covers a wide range of $\delta^{18} \mathrm{O}$ values from +10 to $-10 \%$, but the majority of eclogites $(70 \%)$ fall in the area of isotope equilibrium. Other rocks with positive fractionation $(\Delta \geq 2.2 \%)$ are out of equilibrium, whereas many eclogites (ca. $30 \%$ ) show negative or reverse fractionation, resulting in quartz-omphacite isotope temperatures lower than $400^{\circ} \mathrm{C}$ (Zheng et al. 1999). This phenomenon of disequilibrium has been ascribed to retrograde hydration reactions, in which the responsible 
Table 4 Oxygen isotope data of eclogites and blueschist from the Hong'an Block

\begin{tabular}{|c|c|c|c|c|c|c|c|}
\hline & Rock type & Phase $(\phi)$ & $\delta^{18} \mathrm{O}(\%)$ & No. analysis & $\Delta(\mathrm{Qtz}-\phi)$ & $T^{\circ} \mathrm{C}(\mathrm{Qtz}-\phi)$ & Petro $T\left({ }^{\circ} \mathrm{C}\right)$ \\
\hline \multirow[t]{4}{*}{ XHD07 } & \multirow[t]{4}{*}{ Eclogite } & Grt & $9.4 \pm 0.1$ & 2 & 3.8 & 660 & \multirow[t]{4}{*}{$680-700$} \\
\hline & & Omp & $9.3 \pm 0$ & 2 & 3.9 & 495 & \\
\hline & & Ep & $9.8 \pm 0.1$ & 2 & 3.4 & 553 & \\
\hline & & Qtz & $13.2 \pm 0.1$ & 2 & & & \\
\hline BJ01-107 & Eclogite & Qtz & $13.4 \pm 0.3$ & 2 & & & $680-700$ \\
\hline \multirow[t]{3}{*}{ QJH01 } & \multirow[t]{3}{*}{ Eclogite } & Grt & $3.5 \pm 0$ & 2 & & & \multirow[t]{3}{*}{$610 \pm 40$} \\
\hline & & Rt & - & & & & \\
\hline & & Qtz & - & & & & \\
\hline \multirow[t]{4}{*}{ TP03 } & \multirow[t]{4}{*}{ Eclogite } & Grt & $-3.3 \pm 0$ & 2 & 4.3 & 604 & \multirow[t]{4}{*}{$640 \pm 30$} \\
\hline & & Omp & $-2.8 \pm 0.1$ & 2 & 3.8 & 505 & \\
\hline & & Amp & $-2.9 \pm 0$ & 2 & 3.9 & 589 & \\
\hline & & Ep & $-2.8 \pm 0.1$ & 2 & 3.8 & 508 & \\
\hline P260 & Eclogite & Qtz & $5.8 \pm 0.1$ & 2 & & & $670 \pm 60$ \\
\hline \multirow[t]{5}{*}{ QLP08 } & \multirow[t]{5}{*}{ Eclogite } & Grt & $-7.9 \pm 0.1$ & 2 & 8.2 & & \multirow[t]{5}{*}{$530 \pm 30$} \\
\hline & & Omp & $-7.3 \pm 0.2$ & 2 & 7.6 & & \\
\hline & & Amp & $-8.2 \pm 0$ & 2 & 8.5 & & \\
\hline & & Phen & $-5.7 \pm 0.2$ & 2 & 6.0 & & \\
\hline & & Qtz & - & & & & \\
\hline \multirow[t]{4}{*}{ GQ01 } & \multirow[t]{4}{*}{ Eclogite } & Grt & $8.3 \pm 0$ & 2 & 4.3 & 604 & \multirow[t]{4}{*}{$510 \pm 40$} \\
\hline & & Omp & $8.6 \pm 0.2$ & 2 & 4.0 & 485 & \\
\hline & & Amp & $7.8 \pm 0.1$ & 2 & 4.8 & 504 & \\
\hline & & Qtz & 12.6 & 1 & & & \\
\hline BJ01-101 & Blueschist & Qtz & $9.6 \pm 0.1$ & 2 & & & $350-450$ \\
\hline
\end{tabular}

Note: All analyses were done at the IES, Academia Sinica (TF Yui). Garnet, Omp, Amp, Zoi - by $\mathrm{CO}_{2}$ laser-fluorination method. Phengite and Qtz-by conventional $\mathrm{BrF}_{5}$ method. Precision $= \pm 0.1(\%)$; results relative to SMOW. UWG-2 garnet standard $=$

$+5.8 \%$; NBS-28 standard $=+9.6 \%$. Mass spectrometer used

fluids were probably derived from exsolution of dissolved hydroxyl in UHP metamorphic minerals (Zheng et al. 1999), or the fluids that had equilibrated with low $\delta^{18} \mathrm{O}$ country gneisses (Yui et al. 1997; Zheng et al. 1999). Note that all the six eclogite samples from the Hong'an Block (solid symbols in Fig. 16) have $\Delta{ }^{18} \mathrm{O}$ values close to zero, indicating roughly high-temperature equilibrium between garnet and omphacite, despite the very large range of garnet $\delta^{18} \mathrm{O}$ values ( -8 to $+10 \%$ ). The large range suggests that the protoliths of eclogites have probably been subjected to different histories of water-rock interaction, although other mechanisms could be used to explain such a large spread (e.g., Zheng et al. 1998).

Figure 17 provides another look at the oxygen isotope fractionation between coexisting phases. The oxygen isotope temperatures inferred from the data points of quartz and garnet, or of phengite and garnet appear to agree well with the petrological temperatures given earlier. However, due to the small $\Delta{ }^{18} \mathrm{O}$ values between garnet and omphacite, the isotopic temperatures are quite imprecise and higher than $800^{\circ} \mathrm{C}$, in disagreement with the petrological geothermometry.
= Finnigan MAT 252. Oxygen isotope temperatures calculated using the fractionation factors of Zheng et al. (2003). Factors $\mathrm{A}(\mathrm{Qtz-Grt})=3.31, \mathrm{~A}(\mathrm{Qtz-Omp})=2.30, \mathrm{~A}(\mathrm{Qtz}-\mathrm{Phen})=1.97$,

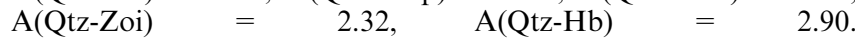

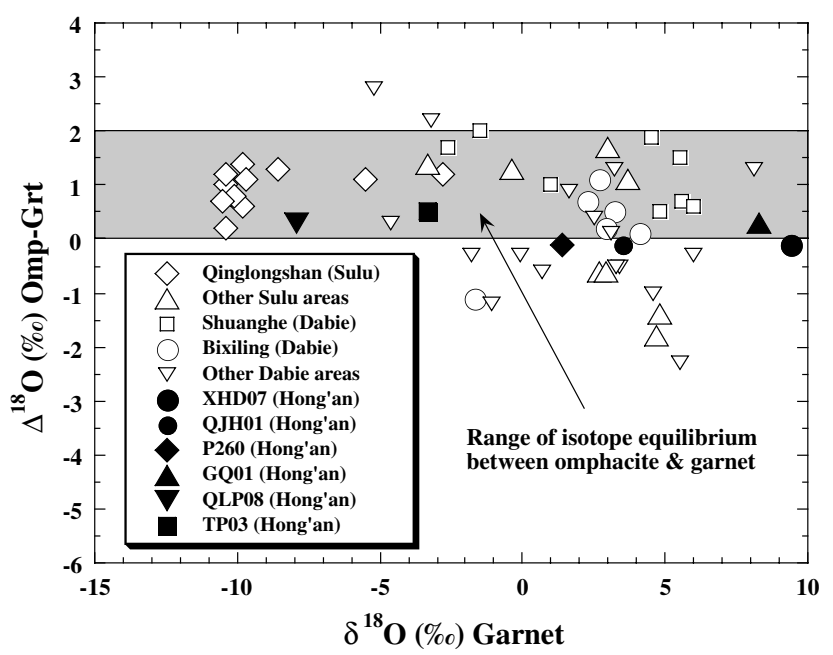

Fig. $16 \Delta{ }^{18} \mathrm{O}$ (Omp-Grt) versus $\delta^{18} \mathrm{O}$ (Grt) plot showing the equilibrium values of oxygen isotope fractionation. Note that almost all Hong'an eclogites show quasi-equilibrium between garnet and omphacite, and that garnets from different localities have very large range of $\delta^{18} \mathrm{O}$, suggesting their distinct premetamorphic histories of water-rock interaction 
One of the most interesting results in isotopic studies of UHP eclogites is the demonstration of a direct correspondence in equilibrium (or disequilibrium) state between the $\mathrm{Sm}-\mathrm{Nd}$ and $\mathrm{O}$ isotopic systems in eclogitic minerals (Zheng et al. 2002). The state of $\mathrm{O}$ isotope equilibrium may provide a critical test for the validity of the $\mathrm{Sm}-\mathrm{Nd}$ mineral isochron ages. Zheng et al. (2002) demonstrated many cases showing coupled $\mathrm{Nd}$ and $\mathrm{O}$ isotopic disequilibrium, and provided the following interpretation. They reasoned that the transformation of a basaltic rock to an eclogite may be expressed by a simplified reaction: $\mathrm{Pl}$ $+\mathrm{Di}=\mathrm{Grt}+\mathrm{Omp}+$ Qtz. In this reaction, the $\mathrm{Si}_{2} \mathrm{O}_{6}$ structural unit in diopside is transferred to omphacite, whereas the $\mathrm{Si}_{3} \mathrm{O}_{8}$ and $\mathrm{Si}_{2} \mathrm{O}_{8}$ units in plagioclase are reorganized to form $\mathrm{SiO}_{4}$ and $\mathrm{SiO}_{2}$ in garnet and quartz, respectively. In an incomplete isotope exchange as observed in the Yangkou eclogite, garnet inherits the oxygen isotope signature of the plagioclase structural units and thus has higher $\delta^{18} \mathrm{O}$ relative to coexisting omphacite, whereas omphacite inherits the oxygen isotope composition of the $\mathrm{Si}_{2} \mathrm{O}_{6}$ structural unit in its precursor diopside with little change in $\delta^{18} \mathrm{O}$ value. Based on the literature data (see summary by Zheng et al. 2002), the rates of O diffusion in garnet and omphacite are lower than, or close to, those of $\mathrm{Nd}$ diffusion at the same temperatures. Consequently, an attainment of $\mathrm{O}$ isotopic equilibrium in the Grt-Omp pair suggests that $\mathrm{Nd}$ isotopic com- positions are homogenized at metamorphic temperatures. Aberrant $\mathrm{Sm}-\mathrm{Nd}$ isochron ages, or no ages at all, are expected to show disequilibrated oxygen isotope fractionation.

The observed near-equilibrium oxygen isotopic fractionations among minerals and aberrant $\mathrm{Sm}-\mathrm{Nd}$ isochron ages in the present samples are obviously in conflict with the above conclusion. This apparent discrepancy, however, could be accounted for by consideration of mass balance and isotopic contrasts between high-temperature refractory inclusions and host minerals. It is possible that the relative amount and isotopic contrast between inclusions and hosts are small in terms of the oxygen system, compared with those of $\mathrm{Sm}-\mathrm{Nd}$ system. That is, the small amount of LREE-rich inclusions may have played a strong role in controlling the $\mathrm{Sm}-\mathrm{Nd}$ isotopic system, hence producing aberrant $\mathrm{Sm}-$ $\mathrm{Nd}$ isochron ages, but they have little effect in modifying the bulk mineral oxygen isotope compositions. Consequently, the near-equilibrium oxygen isotopic fractionations among minerals may only be an apparent feature.

\section{Age of HP/UHP metamorphism in the Hong'an Block}

In this study, the $\mathrm{Sm}-\mathrm{Nd}$ isotopic analyses failed completely to offer any geologically significant isochron ages, but we could still conclude that the age of the HP/
Fig. 17 Correlation in oxygen isotope composition between coexisting minerals of eclogites. Oxygen isotope temperatures are shown (after Zheng 1991, 1993a, 1993b)
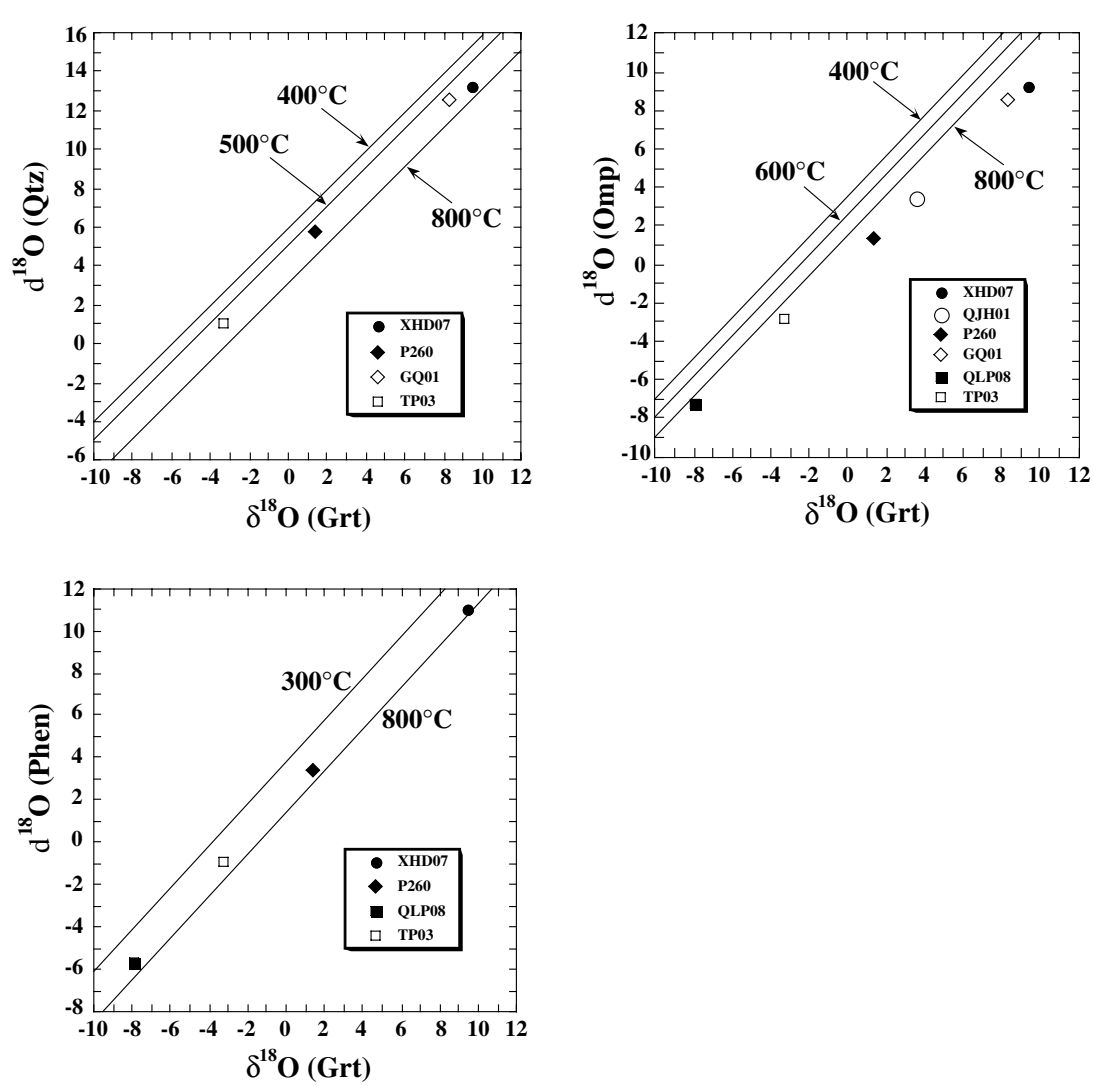
UHP metamorphism in the Hong'an Block is not different from that in the Dabie and Sulu tarranes; i.e., about 220-230 Ma based on many lines of geochronological evidence, as summarized in Table $5 .{ }^{40} \mathrm{Ar}-{ }^{39} \mathrm{Ar}$ data from the literature and our own unpublished work on eclogites and host gneisses consistently show ages about 210-230 Ma, but other dates exhibiting excess $\mathrm{Ar}$ or Ar-loss have also been found (Hacker et al. 2000; Webb et al. 2001). Rb-Sr data, as presented in this work, show isotope disequilibrium in some, but yield meaningful ages of about $220 \mathrm{Ma}$ in other cases. However, our zircon age analysis provided the most convincing evidence for the timing of HP/UHP metamorphism (Liu et al. 2004b).

Zircon may crystallize at low-temperature eclogite facies conditions $\left(\leq 550^{\circ} \mathrm{C}\right)$ in the presence of hydrous fluids (Rubatto et al. 1999; Liermann et al. 2002). However, like in the low- to medium-temperature eclogites from the Hong'an Block, zircon overgrowth is generally too small to be analyzed by the ion microprobe technique. Still worse, some grains did not even grow under the peak metamorphic conditions. Thus, application of the SHRIMP dating to rocks metamorphosed at low temperatures $\left(<600^{\circ} \mathrm{C}\right)$ has been scanty and it remains largely unexplored (Gebauer et al. 1997; Rubatto et al. 1998, 1999; Liati et al. 2002). Liu et al. (2004b) obtained a metamorphic age of $229 \pm 12 \mathrm{Ma}$ for HP eclogite sample QJH01 from the Huwan Unit, and the date is identical to that reported for the Xuanhuadian eclogite in the Hong'an unit $(232 \pm 10 \mathrm{Ma}$; Sun et al. 2002). Meanwhile, a U-Pb age of $213 \pm 5 \mathrm{Ma}$ has also been obtained for the Tianpu UHP eclogite (sample TP03). This age coincides perfectly with the phengitebased $\mathrm{Rb}-\mathrm{Sr}$ isochron age of $212 \pm 7 \mathrm{Ma}$, and hence, it is interpreted as a cooling age of the UHP rocks during exhumation. Furthermore, a lower intercept age of $229 \pm 22$ Ma was obtained for a granitic gneiss (sample $\mathrm{P} 333$ ) by conventional TIMS $\mathrm{U}-\mathrm{Pb}$ analysis. This

Table 5 Summary of radiometric ages for the UHP/HP metamorphic event(s) in the Hong'an Block (numbers in parentheses correspond to reference numbers below)

\begin{tabular}{|c|c|c|c|c|}
\hline Lithotectonic unit (Eclogite Zone) & ${ }^{40} \mathrm{Ar} /{ }^{39} \mathrm{Ar}$ & $\mathrm{Rb}-\mathrm{Sr}$ & $\mathrm{Sm}-\mathrm{Nd}$ & Zircon $\mathrm{U}-\mathrm{Pb}$ \\
\hline Balifan melange unit & $\begin{array}{l}233 \pm 2(2) \\
242 \pm 2(9)\end{array}$ & & & \\
\hline Huwan HP unit(Eclogite Zone I) & $\begin{array}{l}234 \pm 2(2) \\
206 \pm 2(2) \\
432 \pm 4(3) \\
400 \pm 6(3) \\
263 \pm 1(3) \\
230 \pm 1(3) \\
450 \pm 6(9) \\
400 \pm 2(9)\end{array}$ & Failed (8) & $\begin{array}{l}544 \pm 23(4) \\
\text { Failed (8) }\end{array}$ & $\begin{array}{l}400 \pm 2(4) \\
424 \pm 5(5) \\
309 \pm 3(6) \\
229 \pm 12(7)\end{array}$ \\
\hline Xinxian UHP unit(Eclogite Zone III) & $\begin{array}{l}195.2 \pm 0.2(1) \\
222 \pm 2(2) \\
196 \pm 2(2) \\
251 \pm 1(3) \\
187 \pm 1(3)\end{array}$ & $212 \pm 7(8)$ & Failed (8) & $213 \pm 5(7)$ \\
\hline$x^{2}$ & $\begin{array}{l}230.1 \pm 0.4(1) \\
213.3 \pm 0.8(1) \\
224 \pm 2(2) \\
231 \pm 2(2) \\
212 \pm 1(2) \\
247 \pm 2(2) \\
203 \pm 2(2) \\
234 \pm 1(2) \\
207 \pm 1(2) \\
237 \pm 2(2) \\
236 \pm 1(3) \\
215 \pm 1(3) \\
410 \pm 9(9) \\
212 \pm 1(9) \\
208 \pm 1(9) \\
213 \pm 1(9)\end{array}$ & $\begin{array}{l}225 \pm 34(8) \\
210 \pm 4(8)\end{array}$ & Failed (8) & $\begin{array}{l}232 \pm 10(6) \\
229 \pm 22(7)\end{array}$ \\
\hline Mulanshan blueschist-greenschist unit & $\begin{array}{l}225.5 \pm 0.4(1) \\
222.0 \pm 0.3(1) \\
201.3 \pm 0.2(1) \\
198 \pm 2(2) \\
194 \pm 2(2) \\
196 \pm 2(2) \\
231 \pm 1(9)\end{array}$ & $216 \pm 10(8)$ & Failed (8) & \\
\hline
\end{tabular}

References: (1) Eide et al. (1994); (2) Webb et al. (1999); (3) Xu et al. (2000); (4) Jian et al. (1997); (5) Jian et al. (2000); (6) Sun et al. (2002); (7) Liu et al. (2004b); (8) This paper; (9) Liu X. unpublished data.

Note: All the ${ }^{40} \mathrm{Ar} /{ }^{39} \mathrm{Ar}$ ages of $400-450$ Ma were obtained for eclogites. 
sample was collected from the Hong'an unit, about 8-km southwest of sample QLP08. In view of the above consistent zircon ages and the new $\mathrm{Rb}-\mathrm{Sr}$ isochron data, we propose that the peak HP metamorphism in the Hong'an Block occurred at ca. 220-230 Ma, comparable with the peak UHP metamorphic age of the Dabie terrane (Hacker et al. 1998, 2000; Li et al. 2000; Chavagnac et al. 2001; Ayers et al. 2002; Jahn et al. 2003a).

The Xiongdian eclogite from the Huwan HP unit (Fig. 1) has been the subject of geochronological controversy for many years. A detailed discussion on the age problem has been presented most recently by Liu et al. (2004b). A large range of U-Pb zircon ages have been reported, from 400-424 Ma (Jian et al. 1997, 2000), $310 \mathrm{Ma}$ (Sun et al. 2002), to $216 \pm 4 \mathrm{Ma}$ (Gao et al. 2002), and multiple interpretations have been offered. However, the nature of ca. $310 \mathrm{Ma}$ event, as proposed by Sun et al. (2002), still remains obscure. The assumption of a double-suture tectonic setting (Sun et al. 2002), a Carboniferous and a Triassic, lying on the two sides of the Huwan unit cannot be supported with the presently available age data. In fact, the west-converging arcuate structures in the west of the Xinxian unit do not support this hypothesis either. The controversial issue is apparently only limited to the Xiongdian eclogites. We note that these eclogites are characterized by unusually high $\mathrm{SiO}_{2}$ contents $(56-58 \%)$, much higher than in other eclogites $(48 \pm 2 \%)$. This may be attributed to silica metasomatism. Note that the eclogite of Xiongdian recorded the highest temperature $\left(680-700^{\circ} \mathrm{C}\right)$ among all the samples studied; yet, not even the $\mathrm{Rb}-\mathrm{Sr}$ isotope system yields a meaningful isochron age. Perhaps, the metasomatic process has contributed to the added complexity in isotope behavior as well as trace element distribution.

Acknowledgments Joël Macé ably assisted in mass spectrometric analyses reported herein. Klaus Mezger and Yong-Fei Zheng reviewed the manuscript and made many constructive suggestions for clarification and improvement of the final draft. The senior author $(\mathrm{BmJ})$ was initially supported by grants from the French CNRS-INSU. The NSC-Taiwan grants (NSC91-2811-M002-012, NSC92-2811-M-002-056 and NSC92-2116-M-002-024) allowed him to complete this work. Xiaochun Liu was supported by the Major State Basic Research Development Program of China (TG1999075505), Geological Investigation Project of China Geological Survey (200013000169) and Free Research Project of MLR (2002406). He was further supported by the National Science Council of Taiwan for the final preparation of the manuscript. T.F. Yui acknowledges the constant support of NSC.

\section{Appendix 1: Petrographic description of the analyzed samples}

\section{XHD07 and BJ01-107 (eclogite)}

From the same eclogite block (ca. 10-m wide) of Eclogite Zone I (Huwan unit) near Xiongdian. This block has been described by several workers (Jian et al. 1997, 2000; Li et al. 2001; Fu et al. 2002). Eclogite occurs in association with quartzofeldspathic gneiss and marble. The outcrop is banded and strongly foliated. Both samples have a similar mineral assemblage, but differ in modal composition. They consist of garnet, omphacite, phengite, epidote (zoisite), quartz and minor amphibole, calcite, rutile and magnetite. Garnet is euhedral and coarse-grained, with grain sizes of 1-2 mm. It commonly contains numerous inclusions of quartz and calcite in the core (Fig. 18a), and a small amount of rutile and omphacite in the rim. Garnet shows a weak compositional zoning, with spessartine (Sps) decreases and grossular (Grs) increases towards the rim. Pyrope (Prp) (about $24 \mathrm{~mol} \%$ ) and almandine (Alm) remain almost constant. Omphacite is elongated, about $2 \mathrm{~mm}$ in length. It sometimes contains inclusions of quartz and rutile. Omphacite is homogeneous, with jadeite $(\mathrm{Jd})$ content of about $47 \mathrm{~mol} \%$. Epidote is also elongated (ca. 2-3$\mathrm{mm}$ long), and often contains numerous inclusions of omphacite and some garnet, quartz, calcite and rutile (Fig. 18b). Calcite occurs as intergranular grains or intergrowth with phengite. Amphibole is fine-grained $(<1 \mathrm{~mm})$; its occurrence suggests that it is either in textural equilibrium with other minerals, or is a secondary mineral replacing garnet. The calculated $P-T$ conditions are $680^{\circ} \mathrm{C}$ and $15 \mathrm{kbar}$ for the core and $700^{\circ} \mathrm{C}$ and $17 \mathrm{kbar}$ for the rim.

\section{QJH01 (eclogite)}

From an elongated eclogite lens (about 300-m wide) of Eclogite Zone I (Huwan unit) at Qianjinhepeng village. The eclogite comprises garnet, omphacite, amphibole, rutile and minor epidote and quartz. Garnet is euhedral and coarse-grained, with grain sizes of $1-3 \mathrm{~mm}$. It commonly contains numerous inclusions of amphibole, epidote and, rarely, omphacite and paragonite (Fig. 18c). Electron-probe analysis shows a decrease of Sps and Grs and increase of Prp towards the rim. Omphacite is fine-grained ( $\leq 1 \mathrm{~mm}$ ) and strongly oriented. It contains few mineral inclusions and has a rather homogeneous composition with low $\mathrm{Jd}$ content (ca. $25 \mathrm{~mol} \%$ ). Some amphiboles crystallized simultaneously with other minerals, but most, especially those occurring around garnet porphyroblast, formed during the retrograde stage. The peak $P-T$ conditions obtained from garnet and omphacite rims are $610 \pm 40^{\circ} \mathrm{C}$ and $>12$ kbar.

\section{TP03 (eclogite)}

From a lenticular body ( $\sim 10 \mathrm{~m}$ wide) of Eclogite Zone III (Xinxian unit) near Tianpu. It is composed of garnet, omphacite, kyanite, glaucophane, phengite, epidote, 
Fig. 18 Photomicrographs showing paragenesis and inclusion distribution of eclogites from the Hong'an Block. a Garnet enclosing quartz and calcite in the core from sample XHD07 (open polar). b An epidote porphyroblast enclosing omphacite and quartz from sample XHD07 (crossed polar). c Coexisting inclusion-free omphacite and garnet with inclusions of amphibole + epidote + paragonite from sample QJH01 (open polar). d Garnet enclosing phengite, epidote, quartz and rutile from sample TP03 (open polar). e Coexisting fine-grained euhedral garnet and omphacite from sample P260 (open polar). f A large omphacite enclosing small omphacite, epidote and phengite from sample P260 (crossed polar). g Garnets enclosing omphacite, amphibole, rutile and numerous tiny rutiles and possible epidotes from sample QLP08 (open polar). h A garnet porphyroblast containing snowball inclusions of amphibole + epidote + phengite + rutile + titanite from sample GQ01 (open polar). Scale bars are $0.5 \mathrm{~mm}$
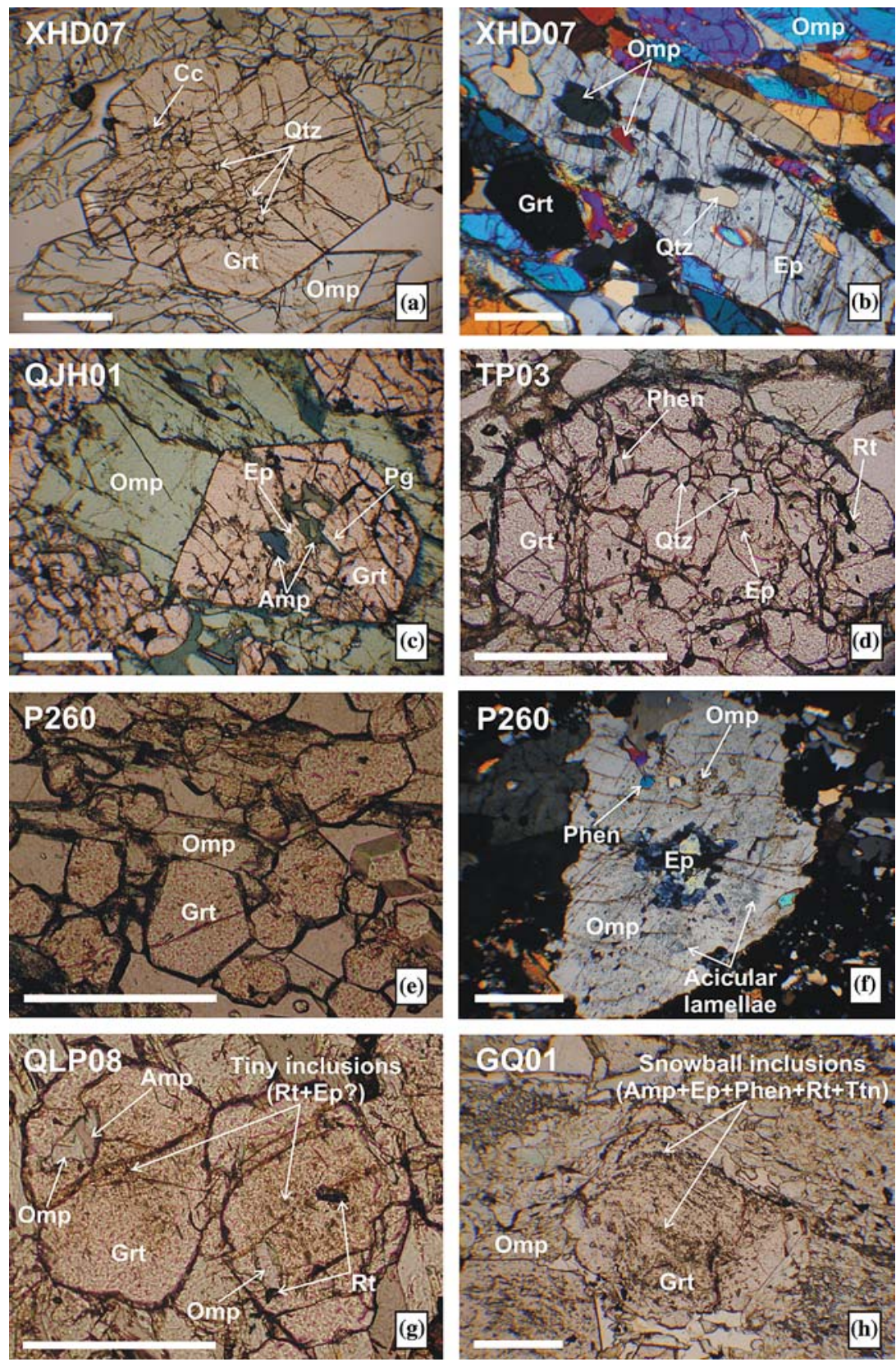

quartz, rutile and minor paragonite. All garnet crystals are fine-grained $(0.1-0.5 \mathrm{~mm})$ and sometimes contain inclusions of amphibole, phengite, epidote, quartz and rutile (Fig. 18d). A quartz pseudomorph after coesite was identified in an annular garnet grain. Garnet is rich in Prp (36-44 $\mathrm{mol} \%$ in the rims) and exhibits pronounced compositional zoning, with a decrease of Sps and Grs and an increase of Prp and Alm from core to rim. Omphacite is coarser than garnet (ca. $0.5 \mathrm{~mm}$ ) and in some cases it contains inclusions of garnet and rutile. Similar to garnet, omphacite also exhibits compositional zoning, with a decrease of acmite (Acm) and an increase of $\mathrm{Jd}$ and augite (Aug) towards the rim. Epidote is coarse-grained (1-2 mm in length) and contains numerous inclusions of garnet, omphacite, kyanite, quartz and rutile. Glaucophane in the matrix occurs as large porphyroblasts, up to $3 \mathrm{~mm}$ in length. It commonly contains inclusions of garnet, kyanite, epidote and quartz. Some reworked glaucophane rims are found in contact with paragonite, indicating a thermal overprinting below the stability of kyanite. Its thermobarometric data are $640 \pm 30^{\circ} \mathrm{C}$ and $29 \pm 3$ kbar.

\section{P260 (eclogite)}

From a large eclogite layer ( $>200 \mathrm{~m}$ wide) of Eclogite Zone III (Xinxian unit) at Xiongjiazhui. The mineral assemblage of this sample is similar to that of sample TP03 except without paragonite. Garnet is euhedral and 
very fine-grained, with grain sizes of $0.05-0.2 \mathrm{~mm}$ (Fig. 18e). Occasionally, it contains minor inclusions of omphacite, epidote and rutile. Garnet is also rich in Prp, with $31-35 \mathrm{~mol} \%$ of Prp in the rims. Omphacite occurs as small grains, or as large crystals up to 1-2 $\mathrm{mm}$. Large omphacite often contains numerous inclusions of small omphacite, garnet, phengite, epidote, quartz and rutile, and tiny, acicular lamellae of nonidentified minerals (Fig. 18f). Jd content of omphacite rims is $43-46 \mathrm{~mol} \%$. As with sample TP03, epidote and glaucophane occur as large crystals and enclose many eclogite facies minerals. $P-T$ conditions for garnet and omphacite rims are estimated to be $670 \pm 60^{\circ} \mathrm{C}$ and $26 \pm 4$ kbar.

\section{QLP08 (eclogite)}

From an eclogite lens of $5 \times 25 \mathrm{~m}^{2}$ of Eclogite Zone IV (north of the Hong'an unit) at Dongyuemiao. The rock shows nearly equigranular texture with grain sizes about $0.4 \mathrm{~mm}$. It consists dominantly of garnet, omphacite, amphibole and epidote, and a subordinate amount of phengite, paragonite, quartz and rutile. Garnet is euhedral and generally encloses numerous tiny rutiles and possible epidotes (Fig. 18g). Some grains are annular and envelop phengite, amphibole, epidote and/or quartz. Such annular garnet shows a two-stage growth, with a decrease of Grs and an increase of Prp towards the rim. Most omphacite is inclusion-free, but some contain minor rutile, garnet, epidote or quartz. Chemical zoning is often found in omphacite grains, with decreasing Acm and increasing Jd and Aug from core to rim. Amphibole is in textural equilibrium with other minerals. The $P-T$ estimates for garnet and omphacite rims are $530 \pm 30^{\circ} \mathrm{C}$ and $20 \pm 2$ kbar.

\section{GQ01 (eclogite)}

From an eclogite block of $>15 \mathrm{~m}$ wide from Eclogite Zone V (south of the Hong'an unit) at Gaoqiao. The sample has a porphyroblastic texture and is composed of garnet + omphacite + phengite + amphibole + epidote + quartz + rutile. Garnet porphyroblast $(0.5-1 \mathrm{~mm}$ in size) commonly contains snowball inclusions of amphibole, epidote, phengite, quartz, titanite and rutile (Fig. 18h). The intergrowth of omphacite + amphibole often occurs as inclusions in its rims. Garnet has the lowest Prp content (only $12-16 \mathrm{~mol} \%$ in rims) among all seven eclogite samples, and shows pronounced compositional zoning with a decrease of Sps and Grs and an increase of Prp and Alm towards the rim. Omphacite occurs as finegrained (about $0.1 \mathrm{~mm}$ ) aggregates in the matrix, but forms the foliation of the rock. Weak chemical zoning is observed with decreasing Acm and increasing $\mathrm{Jd}$ and Aug towards the rim. Amphibole crystallized simultaneously with other minerals, though some occur as porphyroblasts. The peak metamorphic conditions are estimated to be $510 \pm 40^{\circ} \mathrm{C}$ and $20 \pm 1 \mathrm{kbar}$.
BJ01-101 (blueschist)

From the Mulanshan unit. It is a typical acid metavolcanic rock, composed of garnet, glaucophane, phengite, epidote, albite, K-feldspar, quartz and titanite. Garnet is euhedral with grain sizes of $0.5 \mathrm{~mm}$, and usually contains numerous inclusions of phengite, epidote, quartz and titanite. Glaucophane is acicular or columnar, with length up to 1-2 $\mathrm{mm}$. Some large albite and K-feldspar crystals are probably igneous clasts, whereas other finegrained crystals are of metamorphic origin. The $P-T$ conditions of blueschist facies were roughly estimated at $350-450^{\circ} \mathrm{C}$ and $7-10 \mathrm{kbar}$ (Zhou et al. 1993; Liu et al. 2004a).

\section{BJ01-115 (marble)}

From near the village of Qiliping, in Eclogite Zone IV. The rock is dominated by calcite with minor muscovite and quartz. It was formed at a retrograde epidoteamphibolite facies condition of ca. $410 \pm 50^{\circ} \mathrm{C}$ and 5 10 kbar.

\section{References}

Ames L, Tilto GR, Zhou G (1993) Timing of collision of the SinoKorean and Yangtze cratons: U-Pb Zircon dating of coesitebearing eclogites. Geology 21:339-342

Ames L, Zhou G, Xiong B (1996) Geochronology and isotopic character of ultrahigh-pressure metamorphism with implications for collision of the Sino-Korean and Yangtze Cratons, central China. Tectonics 15:472-489

Ayers JC, Dunkle S, Gao S, Miller CF (2002) Constraints on timing of peak and retrograde metamorphism in the Dabie Shan ultrahigh-pressure metamorphic belt, east-central China, using $\mathrm{U}-\mathrm{Th}-\mathrm{Pb}$ dating of zircon and monazite. Chem Geol 186:315-331

Bocchio R, De Capitan L, Ottolini L, Cella F (2000) Trace element distribution in eclogites and their clinopyroxene/garnet pair: a case study from Soazza (Switzerland). Eur J Mineral 12:147-161

Bohlen SR, Boettcher AL (1982) The quartz-coesite transition: a precise determination and the effects of other components. J Geophys Res 87:7,073-7,078

Burton KW, Kohn MG, Cohen AS, O'Nions RK (1995) The relative diffusion of $\mathrm{Pb}, \mathrm{Nd}, \mathrm{Sr}$ and $\mathrm{O}$ in garnet. Earth Planet Sci Lett 133:199-211

Carswell DA, Harley SL (1990) Mineral barometry and thermometry. In: Carswell DA (eds) Eclogite facies rocks. Blackie, New York, pp 83-110

Carswell DA, O'Brien PJ, Wilson RN, Zhai M (1997) Thermobarometry of phengite-bearing eclogites in the Dabie Mountains of central China. J Metam Geol 15:239-252

Chavagnac V, Jahn B-m, (1996) Coesite-bearing eclogites from the Bixiling Complex, Dabie Mountains, China: Sm-Nd ages, geochemical characteristics and tectonic implications. Chem Geol 133:29-51

Chavagnac V, Jahn B-m, Villa IM, Whitehouse MJ, Liu D (2001) Multichronometric evidence for an in situ origin of the ultrahigh-pressure metamorphic terrane of Dabieshan, China. J Geol 109:633-646

Cheng Y, Liu D, Williams IS, Jian P, Zhuang Y, Gao T (2000) SHRIMP U-Pb dating of zircons of a dark-colored eclogite and a garnet-bearing gneissic-granitic rocks. Acta Geol Sin 74:193205 (in Chinese with English abstract) 
Clayton RN, Mayeda TK (1963) The use of bromine pentafluoride in the extraction of oxygen from oxides and silicates for isotopic analysis. Geochim Cosmochim Acta 27:43-52

Cui W, Wang X (1995) Eclogites of southern Henan and northern Hubei Provinces, central China. Island Arc 4:347-361

Dodson MH (1973) Closure temperature in cooling geochronological and petrological systems. Contrib Mineral Petrol 40:259-274

Duchêne S, Blichert-Toft J, Luais B, Télouk P, Lardeaux JM, Albarède F (1997) The Lu-Hf dating of garnets and the ages of the Alpine high-pressure metamorphism. Nature 387:586-589

Eide EA, Liou JG (2000) High-pressure blueschists and eclogites in Hong'an: a frame work for addressing the evolution of highand ultrahigh-pressure rocks in central China. Lithos 52:1-22

Eide EA, Mcwilliams MO, Liou JG (1994) ${ }^{40} \mathrm{Ar} /{ }^{39} \mathrm{Ar}$ geochronology and exhumation of high-pressure to ultrahigh-pressure metamorphic rocks in east central China. Geology 22:601-604

Fu B, Zheng Y-F, Touret JLR (2002) Petrological, isotopic and fluid inclusion studies of eclogites from Sujiahe, NW Dabie Shan (China). Chem Geol 187:107-128

Gao S, Qiu Y, Ling W, McNaughton NJ, Zhang B, Zhang G, Zhang Z, Zhong Z, Suo S (2002) SHRIMP single zircon U-Pb geochronology of eclogites from Yingshan and Xiongdian. Earth Sci 27:558-564 (in Chinese with English abstract)

Gebauer D, Schertl HP, Brix M, Schreyer W (1997) 35 Ma old ultrahigh-pressure metamorphism and evidence for very rapid exhumation in the Dora Maira Massif, Western Alps. Lithos $41: 5-24$

Günther M, Jagoutz E (1997) Isotope disequilibria ( $\mathrm{Sm} / \mathrm{Nd}, \mathrm{Rb} / \mathrm{Sr}$ ) between minerals of coarse grained, low temperature garnet peridotites from Kimberley floors, Southern Africa. In: Meyer HOA, Leonardos $\mathrm{OH}$ (eds) Proceedings of 5th International Kimberlite Conference 1, CPRM Spec Publ 1A (Brasilia), pp 354-365

Hacker BR, Wang X, Eide EA, Ratschbacher L (1996) The Qinling-Dabie ultra-high-pressure collisional orogen. In: Yin A, Harrison MT (eds) The tectonic evolution of Asia. Cambridge University Press, Cambridge, pp 345-370

Hacker BR, Ratschbacher L, Webb LE, Ireland T, Walker D, Dong S (1998) Zircon ages constrain the architecture of the ultrahigh-pressure Qinling-Dabie orogen, China. Earth Planet Sci Lett 161:215-230

Hacker BR, Ratschbacher L, Webb LE, McWilliams MO, Ireland T, Calvert A, Dong S, Wenk H-R, Chateigner D (2000) Exhumation of ultrahigh-pressure continental crust in east central China: late triassic-early jurassic tectonic unroofing. J Geophys Res 105:13339-13364

Holland TJB (1980) The reaction albite $=$ jadeite + quartz determined experimentally in the range $600-1200^{\circ} \mathrm{C}$. Am Mineral 65:129-134

Hoskin PWO, Black LP (2000) Metamorphic zircon formation by solid-state recrystallization of protolith igneous zircon. J Metam Geol 18:423-439

Humphries FJ, Cliff RA (1982) Sm-Nd dating and cooling history of Scourian granulites, Sutherland, NW Scotland. Nature 295:515-517

Jagoutz E (1988) Nd and $\mathrm{Sr}$ systematics in an eclogite xenolith from Tanzania: evidence for frozen mineral equilibria in the continental lithosphere. Geochim Cosmochim Acta 52:1285-1293

Jahn B-m (1990) Early Precambrian basic rocks of China. In: Hall RP, Hughes DJ (eds) Early Precambrian basic magmatism. Blackie, Glasgow, pp 294-316

Jahn B-m (1998) Geochemical and isotopic characteristics of UHP eclogites and ultramafic rocks of the Dabie orogen: Implications for continental subduction and collisional tectonics. In: Hacker B, Liou JG (eds) When continents collide: geodynamics and geochemistry of ultrahigh-pressure rocks. Kluwer, Dordrecht, pp 203-239

Jahn B-m, Liu X (2002) Age (s) of the Hong'an block and the question of $400 \mathrm{Ma}$ UHP metamorphic event. In: International workshop on geophysics and structure geology of UHPM terranes (extended abstract). Beijing, China, pp $68-70$
Jahn B-m, Cornichet J, Cong B, Yui TF (1996) Ultrahigh $\epsilon_{\mathrm{Nd}}$ eclogites from an UHP metamorphic terrane of China. Chem Geol 127:61-79

Jahn B-m, Caby R, Monie P (2001) The oldest UHP eclogites of the World: age of UHP metamorphism, nature of protoliths and tectonic implications. Chem Geol 178:143-158

Jahn B-m, Fan Q, Yang J-J, Henin O (2003a) Petrogenesis of the Maowu pyroxenite-eclogite body from the UHP metamorphic terrane of Dabieshan: chemical and isotopic constraints. Lithos 70:243-267

Jahn B-m, Rumble D, Liou JG (2003b) Geochemistry and isotope tracer study of UHPM rocks (Chapter 12). In: Carswell DA, Compagnoni R (eds) Ultra-high pressure metamorphism. EMU Notes in Mineralogy 5:365-414

Jerde EA, Taylor LA, Crozaz G, Sobolev NV, Sobolev VN (1993) Diamondiferous eclogites from Yakutia, Siberia: evidence for a diversity of protoliths. Contrib Mineral Petrol 114:189-202

Jensen LS (1976) A new cation plot for classifying subalkalic volcanic rocks. Ontario Div Mines Misc Pap, pp 66

Jian P, Yang W, Li Z (1997) Isotopic geochronological evidence for the Caledonian Xiongdian eclogite in the western Dabie Mountains, China. Acta Geol Sin 71:133-141 (in Chinese with English abstract)

Jian P, Liu D, Yang W, Williams IS (2000) Petrographical study of zircons and SHRIMP dating of the Caledonian Xiongdian eclogite, northwestern Dabie Mountains. Acta Geol Sin 74:259264 (in Chinese with English abstract)

Li Hongyan (2003) Crustal evolution of the UHP metamorphic terranes in the Dabie Orogen. Thesis, Université de Rennes 1, France, pp 152

Li S, Xiao Y, Liu D, Chen Y, Ge N, Zhang Z, Sun S-s, Cong B, Zhang R, Hart SR, Wang S (1993) Collision of the North China and Yangtze Blocks and formation of coesite-bearing eclogites: timing and processes. Chem Geol 109:89-111

Li S, Wang S, Chen Y, Zhou H, Zhang Z, Liu D, Qiu J (1994) Excess argon in phengite from eclogite: evidence from dating of eclogite minerals by $\mathrm{Sm}-\mathrm{Nd}, \mathrm{Rb}-\mathrm{Sr}$ and ${ }^{40} \mathrm{Ar} /{ }^{39} \mathrm{Ar}$ methods. Chem Geol 112:343-350

Li S, Jagoutz E, Chen Y, Li Q (2000) Sm-Nd and Rb-Sr isotopic chronology and cooling history of ultrahigh pressure metamorphic rocks and their country rocks at Shuanghe in the Dabie Mountains, central China. Geochim Cosmochim Acta 64:1077-1093

Li S, Huang F, Nie Y, Han W, Long C, Li H, Zhang S, Zhang Z (2001) Geochemical and Geochronological constraints on the suture location between the North and South China Blocks in the Dabie orogen, central China. Phys Chem Earth (A) 26:655-672

Liati A, Gebauer D (1999) Constraining the prograde and retrograde P-T-t path of Eocene HP rocks by SHRIMP dating of different zircon domains: inferred rates of heating, burial, cooling and exhumation for central Rhodope, northern Greece. Contrib Mineral Petrol 135:340-354

Liati A, Gebauer D, Wysoczanski R (2002) U-Pb SHRIMP-dating of zircon domains from UHP mafic rocks in the Rhodope zone (N Greece): evidence for Early Cretaceous crystallzation and Late Cretaceous metamorphism. Chem Geol 184:281-300

Liermann H-P, Isachsen C, Altenberger U, Oberhänsli R (2002) Behavior of zircon during high-pressure, low-temperature metamorphism: case study from the Internal Unit of the Sesia Zone (Western Italian Alps). Eur J Mineral 14:61-71

Liou JG, Zhang RY, Wang X, Eide EA, Ernst WG, Maruyama S (1996) Metamorphism and tectonics of high-pressure and ultrahigh-pressure belts in the Dabie-Sulu region, China. In: Yin A, Harrison MT (eds) The tectonic evolution of Asia. Cambridge University Press, Cambridge, pp 300-344

Liou JG, Zhang RY, Ernst WG, Rumble D, Maruyama S (1998) High-pressure minerals from deeply subducted metamorphic rocks. Rev Mineral 37:33-96

Liu X, Wei C, Li S, Dong S, Liu J (2004a) Thermobaric structure of a traverse across western Dabieshan: implications for collision tectonics between the Sino-Korean and Yangtze cratons. J Metam Geol 22:361-379 
Liu X, Jahn B-m, Liu D, Dong S, Li S (2004b) SHRIMP U-Pb zircon dating of a metagabbro and eclogites from western Dabieshan (Hong'an Block), China, and its tectonic implications. Tectonophysics 394:171-192

Luais B, Duchene S, de Sigoyer J (2001) Sm-Nd disequilibrium in high-pressure, low-temperature Himalayan and Alpine rocks. Tectonophysics 342:1-22

Ludwig KR (1999) Isoplot/Ex (v. 2.01) — a geochronological toolkit for Microsoft Excel. Berkeley Geochronology Center, Special Publication, No. 1a, pp 49

Maruyama S, Tabata H, Nutman AP, Morikawa T, Liou JG (1998) SHRIMP U-Pb geochronology of ultrahigh-pressure metamorphic rocks of the Dabie Mountains, central China. Cont Dynam 3:72-85

Mezger K, Essene EJ, Halliday AN (1992) Closure temperatures of the $\mathrm{Sm}-\mathrm{Nd}$ system in metamorphic garnets. Earth Planet Sci Lett 113:397-409

Middlemost EAK (1994) Naming materials in the magma/igneous rock system. Earth- Sci Rev 37:215-224

Newton RC (1986) Metamorphic temperatures and pressures of Group B and C eclogites. In: Evans BW, Brown EH (eds) Blueschists and eclogites. Geol Soc Am, Boulder, pp 17-30

Pidgeon RT (1992) Recrystallisation of oscillatory zoned zircon: some geochronological and petrological implications. Contrib Mineral Petrol 110:463-472

Pidgeon RT, Nemchin AA, Hitchen GJ (1998) Internal structures of zircons from Archaean granites from the Darling Range batholith: implications for zircon stability and the interpretation of zircon U-Pb ages. Contrib Mineral Petrol 132:288-299

Powell R (1985) Regression diagnostics and robust regression in geothermometer/geobarometer calibration: the garnet-clinopyroxene geothermometer revisited. J Metam Geol 3:231-243

Powell R, Holland T, Worley B (1998) Calculating phase diagrams involving solid solutions via non-linear equations, with examples using Thermocalc. J Metam Geol 16:577-588

Ratschbacher L, Hacker BR, Calvert A, Webb LE, Grimmer JC, Mcwilliams MO, Ireland T, Dong S, Hu J (2003) Tectonics of the Qinling (Central China): tectonostratigraphy, geochronology, and deformation history. Tectonophysics 366:1-53

Rowley DB, Xue F, Tucker RD, Peng ZX, Baker J, Davis A (1997) Ages of ultrahigh pressure metamorphism and protolith orthogneisses from the eastern Dabie Shan: $\mathrm{U} / \mathrm{Pb}$ zircon geochronology. Earth Planet Sci Lett 151:191-203

Rubatto D, Gebauer D, Fanning M (1998) Jurassic formation and Eocene subduction of the Zermatt-Saas-Fee ophiolites: implications for the geodynamic evolution of the Central and Western Alps. Contrib Mineral Petrol 132:269-287

Rubatto D, Gebauer D, Compagnoni R (1999) Dating of eclogitefacies zircons: the age of Alpine metamorphism in the SesiaLanzo Zone (Western Alps). Earth Planet Sci Lett 167:141-158

Sassi R, Harte B, Carswell DA, Han Y (2000) Trace element distribution in central Dabie eclogites. Contrib Mineral Petrol 139:298-315

Sharp ZD (1990) A laser-based microanalytical method for the in situ determination of oxygen isotope ratios of silicates and oxides. Geochim Cosmochim Acta 54:1353-1357

de Sigoyer J, Chavagnac V, Blichert-Toft J, Villa I, Luais B, Guillot S, Cosca M, Mascle G (2000) Dating the Indian continental subduction and collisional thickening in the northwest Himalaya: multichronology of the Tso Morari eclogites. Geology 28:487-490

Snyder GA, Jerde EA, Taylor LA, Halliday AN, Sobolev VN, Sobolev NV (1993) Nd and $\mathrm{Sr}$ isotopes from diamondiferous eclogites, Udachnaya Kimberlite Pipe, Yakutia, Siberia: evidence of differentiation in the early Earth? Earth Planet Sci Lett 118:91-100

Sun W, Williams IS, Li S (2002) Carboniferous and Triassic eclogites in the western Dabie Mountains, east-central China: evidence for protracted convergence of the North and South China Blocks. J Metam Geol 20:873-886
Tatsumi Y, Nakashima T, Tamura Y (2002) The petrology and geochemistry of calc-alkaline andesites on Shodo-Shima Island, SW Japan. J Petrol 43:3-16

Thöni M (2002) Sm-Nd isotope systematics in garnet from different lithologies (Eastern Alps): age results, and an evaluation of potential problems for garnet $\mathrm{Sm}-\mathrm{Nd}$ chronometry. Chem Geol 185:255-281

Valley JW, Matthew NM, Kohn J, Niendorf CR, Spicuzza MJ (1995) UWG-2, a garnet standard for oxygen isotope ratios: Strategies for high precision and accuracy with laser heating. Geochim Cosmochim Acta 59:5223-5231

Wang X, Jing Y, Liou JG, Pan G, Liang W, Xia M, Maruyama S (1990) Field occurrences and petrology of eclogites from the Dabie Mountains, Anhui, central China. Lithos 25:119-131

Webb LE, Hacker BR, Ratschbacher L, McWilliams MO, Dong S (1999) Thermochronologic constraints on deformation and cooling history of high- and ultrahigh-pressure rocks in the Qinling-Dabie orogen, eastern China. Tectonics 18:621638

Webb LE, Ratschbacher L, Hacker BR, Dong S (2001) Kinematics of exhumation of high- and ultrahigh-pressure rocks in the Hong'an and Tongbai Shan of the Qinling-Dabie collisional orogen, eastern China. In: Hendrix MS, Davis GA (eds) Paleozoic and Mesozoic tectonic evolution of central Asia: from continental assembly to intracontinental deformation, Memoir 194, Geol Soc Am, Boulder, pp 231-245

Whitney D (1996) Garnets as open systems during regional metamorphism. Geology 24:147-150

Xie Z, Zheng Y-F, Jahn B-m, Ballevre M, Chen J-F, Gautier P, Gao T-S, Gong B, Zhou J-B (2004) Sm-Nd and Rb-Sr dating of pyroxene-garnetite from North Dabie in east-central China: problem of isotope disequilibrium due to retrograde metamorphism. Chem Geol 206:137-158

$\mathrm{Xu} \mathrm{B}$, Grove M, Wang C, Zhang L, Liu S (2000) ${ }^{40} \mathrm{Ar} /{ }^{39} \mathrm{Ar}$ thermochronology from the northwestern Dabie Shan: constraints on the evolution of Qinling-Dabie orogenic belt, east-central China. Tectonophysics 322:279-301

Yang JS, Wooden JL, Wu CL, Liu FL, Xu ZQ, Shi RD, Katayama I, Liou JG, Maruyama S (2003) SHRIMP U-Pb dating of coesite-bearing zircon from the ultrahigh-pressure metamorphic rocks, Sulu terrane, east China. J Metam Geol 21:551-560

Yui TF, Rumble D, Lo CH (1995) Unusually low $\delta^{18} \mathrm{O}$ ultrahighpressure metamorphic rocks from the Sulu terrain, eastern China. Geochim Cosmochim Acta 59:2859-2864

Yui TF, Rumble D, Chen CH, Lo CH (1997) Stable isotope characteristics of eclogites from the ultrahigh-pressure metamorphic terrains, east-central China. Chem Geol 137:135-147

Zhang RY, Liou JG (1994) Coesite-bearing eclogite in Henan Province, central China: detailed petrography, glaucophane stability and $P-T$ path. Eur J Mineral 6:217-233

Zheng Y-F (1991) Calculation of oxygen isotope fractionation in metal oxides. Geochim Cosmochim Acta 55:2299-2307

Zheng Y-F (1993a) Calculation of oxygen isotope fractionation in anhydrous silicate minerals. Geochim Cosmochim Acta 57:1079-1091

Zheng Y-F (1993b) Calculation of oxygen isotope fractionation in hydroxyl-bearing silicates. Earth Planet Sci Lett 120:247-263

Zheng Y-F, Fu B, Li Y, Xiao Y, Li S (1998) Oxygen and hydrogen isotope geochemistry of ultrahigh-pressure eclogites from the Dabie Mountains and the Sulu terrane. Earth Planet Sci Lett 155:113-129

Zheng Y-F, Fu B, Xiao Y, Li Y, Gong B (1999) Hydrogen and oxygen isotope evidence for fluid-rock interactions in the stages of pre- and post-UHP metamorphism in the Dabie Mountains. Lithos 46:677-693

Zheng Y-F, Wang Z, Li S, Zhao Z (2002) Oxygen isotope equilibrium between eclogite minerals and its constraints on mineral Sm-Nd chronometer. Geochim Cosmochim Acta 66:625-634

Zheng Y-F, Zhao Z, Li S, Gong B (2003) Oxygen isotope equilibrium between ultrahigh-pressure metamorphic minerals and 
its constraints on $\mathrm{Sm}-\mathrm{Nd}$ and $\mathrm{Rb}-\mathrm{Sr}$ chronometers. In: Vance D, Müller W, Villa IM (eds) Geochemistry: linking the isotopic record with petrology and textures. Geol Soc London, Spec Publ 220:93-117

Zhong Z, Suo S, You Z (1999) Regional-scale extensional tectonic pattern of ultrahigh-P and high-P metamorphic belts from the Dabie massif, China. Inter Geol Rev 41:1033-1041
Zhong Z, Suo S, You Z, Zhang H, Zhou H (2001) Major constituents of the Dabie collisional orogenic belt and partial melting in the ultrahigh-pressure unit. Inter Geol Rev 43:226-236

Zhou B, Hensen BJ (1995) Inherited Sm/Nd isotope components preserved in monazite inclusions within garnets in leucogneiss from East Antarctica and implications for closure temperature studies. Chem Geol 121:317-326 